\title{
INVISIBLE CITIES: THE CONSTITUTIONAL STATUS OF DIRECT DEMOCRACY IN A DEMOCRATIC REPUBLIC
}

\author{
DOUGLAS H. HSIAO
}

Studying how direct deinocracy ${ }^{1}$ works in the United States feels a bit hike watching a Harold Pinter play. Pinter takes perverse and misogynistic people and presents thein in a context with which we are familiar and comfortable-the family hiving room. We see hit nien who talk about the boredom of waiting for their next assignment ${ }^{2}$ and the father who presents the family offer to his eldest son's wife for her concubine services. ${ }^{3}$ Our eyes see a family living rooln, but our ears hear soinething entirely different. We try to accept then as though they are part of our world. They are, in fact, completely severed from our moral context; we instinctively try to place them in our context but are unable. The referendum and imitiative are, in the same way, severed from our contextour constitutional context-but we do not realize it.

One feels the same uneasiness with direct deniocracy as witl watching Pinter's plays, but one cannot identify the source of these feelings. The power of direct deniocracy lies in its rhetorical "feel"; it "looks" and "sounds" like it is part of our constitutional fabric. Who can really disagree with power in the liands of the people?4 But direct democracy warps our republican constitutional scleme while cloaking itself behind the cloth of its vocabulary: deniocracy and popular sovereignty.

1. Direct democracy refers to the referendum, the initiative, and the recall. Although most commentators treat all threc together, this Note will use direct democracy as a shorthand term for only the referendum and initiative. The referendum is a mandatory vote to approve or disapprove a law passed by the legislature. Thomas E. Cronin, Direct Democracy: The Politics of InitiATIVE, REFERENDUM, AND RECALL 2 (1989). An initiative is a law that is written and voted upon by the populace. Id. The recall, as a voting device, more closely minics what voters are supposed to do: choose their representatives. The recall allows voters to discharge duly elected officials from their offices by vote. Id. at 125 . It is a device of a different kind. Even though there are dangers inherent in the recall, these would be more properly treated in a different work.

2. See Harold Pinter, The Dumb Waiter, in Twentieth Century Drama: ENGLand, IRELAND, THE UNITED STATES 622 (Ruby Cohn \& Bernard F. Dukore eds., 1966).

3. See Harold Pinter, The Homecoming (1965).

4. Even the term "direct democracy" conveys an idea that one finds hard to reject. I use the term because it is the most familiar shorthand for referenda, initiatives, and recalls. Some other writers prefer other, less biased terms such as "direct legislation." See, eg., DAvid B. MAGLEBY, Direct Legislation: Voting on Ballot Propostions in the United States (1984). 
The historian Edmund Morgan identifies the idea of popular sovereignty as the source of direct democracy and the poimt at which we began to distort and separate from our Republic:

The political world of make-believe mingles witl the real world in strange ways, for the make-believe world may often mold the real one. In order to be viable, in order to serve its purpose . . . a fiction must bear some resemblance to fact. If it strays too far from fact, the willing suspension of disbelief collapses. And conversely it may collapse if facts stray too far from the fiction that we want thein to resemble. Because fictions are necessary ... we often take pains to prevent their collapse by moving the facts to fit the fiction, by making our world conform more closely to what we want it to be. We soinetimes call it, quite appropriately, reform or reformation, when the fiction takes cominand and resliapes reality. ${ }^{5}$

Morgan's point is that we create fictions to gloss over tlose things that we cannot accept. And as facts seem to conflict with our fiction, we do not abandon tlie fiction; ratler, we distort the facts to make tliein fit within the fiction. In the same way, we created the fiction of popular sovereignty (the idea that the people are the wellspring of all political power) because we could not face the reality of being a people of the many led by the few. The people began to realize at the end of the nineteentli century that, at bottom, popular sovereignty had little real meaning, that they were lielpless to exert direct control on their governance. Gigantic corporations seemed to dominate their entire existence, ${ }^{6}$ and politicians were simply venal. ${ }^{7}$ Instead of abandonimg tlie fiction of popular sovereignty, the progressives of the early twentietli century moved "tlie facts to meet the fiction" by inventing direct democracy. Those supporters of direct democracy waved the flag of popular sovereignty; but, if Morgan is riglit, they were waving a long-faded banner.

Consider this Note an attempt to put direct democracy back into our constitutional context and to examine whether it belongs there. From the very beginning, there was a meaningful and vigorous debate over the wisdom of direct democracy. ${ }^{8}$ Proponents of direct democracy

5. Edmund S. Morgan, Inventing the People: The Rise of Popular Sovereignty IN ENGLAND AND AMERICA 14 (1988) (emphasis added); see also id. at 54 ("Was there any way that ... the whole people, the fictional people, could materialize and act apart from their representatives ...? New answers, new devices to bring the facts toward the fiction are invented from time to time.").

6. See Richard Hofstadter, THE AGE OF REFORM: From BRYAN TO F.D.R. 74 (1955).

7. See id. at 184 .

8. See, eg., James Boyle, The Initiative and Referendum: Its Folly, Fallacies, AND FAILURE 15 (3d ed. 1912) (early polemic against direct democracy with the assertion on its cover, "This book tells you what you ought to know"). 
glorified their cause and impugned the motives of their opponents, ${ }^{9}$ while opponents gleefully noted that Napoleon and Adolph Hitler thought direct democracy was a useful tool to their designs on power. ${ }^{10}$ But in recent times, as the number of referenda and initiatives have exploded upon the political landscape, few voices have been raised in protest. Like having a bear seated at the dinner table, the people feed it to keep it happy while never asking why it sat to dine in the first place. ${ }^{11}$

The recent rise in the use of direct democracy has been attributed to the people's disaffection with the legislative process. ${ }^{12}$ When particular passions catch hold of the people, they become frustrated with the snaillike pace of legislative action. ${ }^{13}$ Legislatures that avoid the tough issues or handle the tough issues with poor results have, instead of solving the problems internally, given over their imprimatur to a wave of measures prompted by the people. Referenda and initiatives in the 1980s have covered some of the most contentious areas of politics: gun control, ${ }^{14}$ enviroumental law, ${ }^{15}$ the right to die, ${ }^{16}$ Enghish as a state's official language, ${ }^{17}$ tax refunds and caps, ${ }^{18}$ the criminalization of marijuana, ${ }^{19}$ and legislative term limitations. ${ }^{20}$ They reflect a growing frustration with the pohtical process and attempt to preempt a rational legislative process.

9. See Judson King, The State-Wide Initiative and Referendum, S. Doc. No. 736, 64th Cong., 2d Sess. 5 (1917) ("Organizations of the producing classes such as farmer's unions, granges, labor organizations, and reform leagues are for them. They are strenuously opposed by all the big trusts and corporations, the reactionary politicians of all parties, nearly all the corporation lawyers, and every corrupt political boss in the United States.").

10. See Carl J. Friedrich, Constitutional Government and Democracy: Theory AND Practice In EURope AND AMERICA 536-67 (rev. ed. 1950).

11. Alasdair MacIntyre's allegory of the moral catastrophe inay be more appropriate than inine. MacIntyre supposes that there was a catastrophe in the history of humanity after which we recovered all the words of our inorality but had no real context to understand what they really meant. We still continue to use the words, but our use of them is really nonsense. See ALASDAIR MACINTYRE, AFTER VIRTUE 1-5 (2d ed. 1984).

12. See Robert Pear, Number of Ballot Initiatives Is the Greatest Since 1932, N.Y. TimES, Nov. 5,1990 , at A11.

13. A classic account of the unbridled passions of the people can be found in the story of Coriolanus. See William Shakespeare, Coriolanus.

14. See Cal. Prop. No. 15 (1982).

15. See Cal. Prop. No. 128 (1990) [hereinafter Big Green].

16. See Wash. Imit. No. 119 (1991).

17. See Cal. Prop. No. 63 (1986).

18. See Mass. Measure No. 3 (1986).

19. See Alaska Ballot Measure No. 2 (1990).

20. See, e.g., Cal. Prop. No. 140 (1990); Colo. Amend. No. 5 (1990); Wash. Init. No. 552 (1991). The irony of term limitations should not be lost. On the one hand the people seem to be saying "We hate you!" but on the other, "I can't stop inyself from voting for you!" Term limitations are like voluntary commitment; we fear our own irrationality. But, humior aside, the paradox points out a more fundamental truth about voting behavior; as Arrow noted, there is no one distinct voice of the people. The majority is statistically unpredictable and contradictory. See KENNETH ARRow, Collective ChoICE AND INDIVIDUAL VAlues (2d ed. 1963); see also Bernard Grofman 
This Note does not argue that all referenda and initiatives are products of iconoclastic impulses. Direct democracy comes from both the left and the right, reflecting both the best of progressive populisin and the worst of the reactionary. But the wheat, here, cannot be separated from the chaff. Direct democracy provides a dangerous outlet for disaffected groups with racial biases or special interests who try to impose their narrow, limiting vision on society. This Note concludes that direct democracy can only lead to a majoritarian, superficial hornogeneity and, at worst, to the tyranny of the majority.

Recent commentators have acquiesced to direct democracy's existence while wondering how to control it..21 George Will22 and Derrick Bell $^{23}$ have railed against direct deinocracy while Ralph Nader and the reactionary American Enghish movernent espouse its use. Conservatives do not seem to know which side to take: The American Enterprise Institute has crusaded against the device, ${ }^{24}$ while conservative tax reforiners like Howard Jarvis and Paul Gann gained their faine through direct democracy. ${ }^{25}$ Those on the left, too, have grave inisgivings about the dangers of uncontrolled inajorities. ${ }^{26}$ This kind of confusion is a product of cognitive dissonance-the Pinteresque quality-caused when the rhetoric of direct deınocracy feels right, but our mind cannot fully accept it. Like opposing soldiers wearing the saine uniforns, the hazy line of "who's on my side" is no longer so clear, and we look more fondly upon battles where two trenches faced each other and let the bullets fly without regret. ${ }^{27}$ That is what progressives find so utterly mystifying, how to both acknowledge the grandeur of direct democracy while attacking it as the excess of power. Opponents of direct deinocracy should never grant

\& Scott Feld, Democratic Theory and the Public Interest: Condorcet and Rousseau Revisited, 83 AM. PoL. ScI. Rev. 1317, 1320-21 (1989) (describing how the Arrow Theorem and the French political philosophers Rousseau and Condorcet relate); id. at 1335 (justifying representative democracy because of "practical impossibility of a pure democratic form" shown by Condorcet).

21. See, eg., Julian N. Eule, Judicial Review of Direct Democracy, 99 Y ALE L.J. 1503 (1990).

22. See, e.g., George F. Will, Back to Basics in California, WASH. PosT, Oct. 25, 1990, at A23. ("Recourse to ballot propositions represents rejection of the core principle of representative government: The people do not decide issues, they decide who shall decide.").

23. See Derrick A. Bell, Jr., The Referendum: Democracy's Barrier to Racial Equality, 51 WASH. L. REV. 1 (1978).

24. See American ENTERPrise INSTItUTE, The Referendum Device (Austin Ranney ed., 1981) (symposium organized by the American Enterprise Institute to critique direct democracy).

25. See Amy Pyle, Festivities Honor Jarvis, Gann on 10th Anniversary of Proposition 13, L.A. Times, June 6, 1988, at B11.

26. See Eule, supra note 21 , at 1584 .

27. Professor Eule's conclusion to his article is illustrative of this kind of liberal uncertainty, what he calls his "lingering doubt." See Eule, supra note 21, at 1584-86; see also H.N. Hirsch, The Threnody of Liberalism: Constitutional Liberty and the Renewal of Community, 14 POL. THEORY 423 (1986). Hirsch is less than sympathetic to liberalism: The word "threnody" is a kind of mournful dirge. 
the proponents their basic premise that it has some hallowed place in our Republic. Direct democracy is not "pure" democracy but is rather a perversion of democracy, or, as Tom Stoppard might say, a travesty. ${ }^{28}$

This Note argues in Part I that any project that suggests to reform the direct democracy process is doomed from the beginning. The history of the direct democracy movement shows that it was built on false pretenses, and any reform-regardless low well-meaning - can only fail, or worse, exacerbate the problem. Part I focuses on the recent work of Juhan Eule ${ }^{29}$ and other reformers of direct democracy who have argued that direct democracy should be subject to more stringent judicial review. This Note, although agreeing in principle witl Eule that direct democracy has serious flaws, disagrees with his proposed solution. Eule wants to have it both ways: to preserve the device but to curb its use. I argue that direct democracy is unconstitutional. The "progressive" project must be scrapped, no matter how drastic this solution appears at first . blush. Maintaining the status quo does far more damage to our democratic Republic than to abandon this travesty of one.

Direct democracy has no place in the scheme allowed by our Constitution or envisioned by the Framers of this Republic. As James Madison observed, the aggregation of the power of governance in one source is the very definition of tyranny. ${ }^{30}$ Once one begins to understand the ineaning of both Madison's philosophy and the constitutional Guaranty of a Republican Form of Government, ${ }^{31}$ the "make-behieve" quality of direct democracy will begin to expose itself.

The constitutional context into which direct denrocracy inust be placed is not bereft of any poimts of reference. One need not rewrite the Constitution to find that direct democracy does not fit within it. In fact, the Framers gave the federal government a powerful tool, the Guaranty to the states of a Republican Form of Government. Although the states were, in a sense, laboratories of the Republic-to experiment with different forns of government-these experiments could not go outside the bounds of what would be acceptable under tlie Constitution. The Guaranty Clause ${ }^{32}$ set such a limit on tlie laboratory. Part II of this Note shows low tlie Guaranty of a Republican Form of Government can be read to find direct denlocracy out of bounds in our constitutional scheme.

28. See TOM Stoppard, Travesties (1975). Stoppard meant a travesty as not merely in the colloquial sense, but as being a "broad and grotesque parody on a lofty work or theme." AMERICAN Heritage Dictionary' 1290 (2d. college ed. 1985).

29. See Eule, supra note 21.

30. See The Federalist No. 47, at 211 (James Madison) (Charles A. Beard ed., 1948).

31. See U.S. CONST. art. IV, § 4.

32. I will refer to Article IV, Section 4 of the Constitution as the Guaranty Clause. 
The first obstacle to such a conclusion, however, is the traditional (and anachronistic) view that the Guaranty Clause is nonjusticiable. In two separate but intertwined decisions, Luther v. Borden ${ }^{33}$ and Pacific States Telephone \& Telegraph v. Oregon, ${ }^{34}$ the Supreme Court held that any issue concerning the Guaranty Clause was a political question that the courts could not and would not answer. Since the beginning of this century when these cases were decided, the courts have held fast to the nonjusticiability of the Guaranty Clause, while at the same tine the political question doctrine itself has been crumbling. Part II(A) will examine the history of the political question doctrine beginning with $\mathrm{Lu}$ ther v. Borden and Pacific States. It will next examine the shaky status of that doctrine smce Baker v. Carr ${ }^{35}$ and conclude that it is inconsistent with precedent and the present state of the political question doctrine to hold the Guaranty Clause non-justiciable.

Finally, Part II(B) argues that the Guaranty Clause bars the use of direct democracy by the states because it is not a Republican Forn of Government. What nany might find unsatisfying about recent commentary on the Clause is that virtually no one will venture a definition of "republican." Without outlining some contours of the ineaning of "republican," determining the constitutionality of direct democracy would be imipossible. This Note argues that neither the fiction of popular sovereignty nor any past or current ineaning of "republican" can support the constitutionality of direct democracy. The Framers of the Constitution never intended that any state be allowed to have any direct form of deinocracy in the governance of the state's affairs. The Federalist Papers and other historical documents make this clear. ${ }^{36}$ The political tlinkers who contributed to designing the blueprint for the United States drew a sharp distimction between what was a republic and what was a democracy. They thought that the United States would be a republic-not a democracy-and that the Guaranty Clause would nake this decision exphicit. The definition of what is republican, then, necessarily excludes that which is democratic.

Recent pohtics have blurred the distinction between republican and democratic to the point where inost Americans today would probably think the terms synonymous. ${ }^{37}$ The civic republican novement has emerged to realign American political thought with its republican roots

\footnotetext{
33. 48 U.S. (7 How.) 1 (1849).

34. 223 U.S. 118 (1912).

35. 369 U.S. 186 (1972).

36. See infra text accompanying notes 206-17.

37. And to confuse matters even more, our political parties also use the terms democratic and republican.
} 
and to distinguish it from rank deinocracy. The question then becomes whether the emerging definition of republican reserves a place for direct democracy. This Note identifies the significant anti-republican aspects of direct democracy and cautions civic republicans tempted by its siren song. In so doing, it addresses the important treatments of civic republicanism by Michael Walzer ${ }^{38}$ and Benjamin Barber. ${ }^{39}$ They illustrate the two approaches: Walzer finds republicanism and direct democracy incompatible; Barber finds them perfectly compatible. They reach these diametrically opposed positions because they have different conceptions of republicanism. Walzer refuses to stray too far from the civic republican idea of community and thus is led to reject direct democracy..$^{40} \mathrm{Bar}$ ber advocates direct democracy in his community but has to strain the meaning of community to sucli a degree as to make his framework nonsensical. ${ }^{41}$ This Note concludes that contemporary republicans sliould see that direct democracy is contradictory to the logic of republicanism. No meaning of "republican" garnered from history, from the Framers, or even from contemporary republicans can shield direct democracy under its umbrella. The Guaranty Clause must lead courts to find direct democracy unconstitutional.

In Invisible Cities, ${ }^{42}$ Italo Calvino imagines Kublai Khan sitting with Marco Polo and histening to the stories of the wondrous cities that Polo encountered in his travels. These cities are "invisible" because they exist solely in the minds of the two men, one through inagination, one through meinory. ${ }^{43}$ But the stories that Marco Polo relates really tell a story about how people create their desires and then shape tlie world around tliose desires. The desires-or what I have called fictions-take hold of reality and create, out of whole cloth, new worlds and new cities that have an existence (if any) only in the mind.

Direct democracy is a manifestation of our deepest political desires. We passionately want to see that our government of the people, by the people, and for the people does not perish from this earth. But these desires have taken control of reality-making direct democracy fit with our Republic when in fact it has nothing to do with our Republic. To the citizen, direct democracy is "the city of his dreams." 44 But Calvino says

38. See Michael Walzer, Spheres of Justice: A Defense of PluRalism and EqualITY (1983).

39. See Benjamin Barber, Strong Democracy: Participatory Politics for a New AGE (1984).

40. See WALZER, supra note 38 , at 304.

41. See Barber, supra note 39 , at $150-56$.

42. Italo Calvino, Invisible Cities (William Weaver trans., 1974).

43. Id. at 5.

44. Id. at 8. 
there is "one difference" between the real city and the dreamed-of city: "The dreamed-of city contained him as a young man; he arrives at [the real city] in his old age. In the square there is the wall where the old men sit and watch the young go by; he is seated in a row with thein. Desires are already meinories." 45 Soinetimes our own desires outstrip reality, and when we arrive at reality, we are shocked to find that we are only living out an empty dream. Regretfully, direct democracy is one dream that has imposed itself upon and twisted our Constitution. The longer we live with the dream of direct democracy, the desires for direct dennocracy become inemories that direct democracy always existed.

\section{Flying Buttresses, Filtering, AND the Failure of JUDICIAL REVIEW}

Flying buttresses stand as a testament to gothic architecture's inisunderstanding of the physical laws of gravity. Medieval architects wanted their cathedrals to soar to the heavens but could not do so without the walls collapsing under the huge force of the weight above. So the architects created a new kind of support-the flying buttress-to make up for their mistakes rather than rethinking the theory behind the cathedral design. The structure of direct democracy is like a gothic cathedral that needs support from below by the buttressing of the Equal Protection Clause, the Due Process Clause, the First Amendment, and state-created procedures. The higher direct deinocracy has sought to soar in the twentieth century, the inore necessary has the heavy buttressing from judicial review becoine. We have arrived at a stage where the flying buttresses have corrupted the pristine vision of direct democracy. This vision of direct democracy has been corrupted wholly because the original blueprint was laid upon a faulty architectural foundation-what historians have identified as the myth of popular sovereignty.

\section{A. Mythmaking: The Rise of Direct Democracy in the Twentieth Century}

In the early 1900 s, the pohtical machines and large corporations became the targets of a new politics: the progressive moveinent. Richard Hofstadter's definitive history of this era describes the movement's goal:

45. Id. A more accessible expression of Calvino's ideas can be found in a Doonesbury cartoon by Garry Trudeau. The scene: Michael Doonesbury and Zonker walk in the snowy forest outside their home. Zonker recalls all the frivolity and pranks of their college years. Doonesbury pauses.

Doonesbury: Uh . . . Zonker?

Zonker: Yes, Mike?

Doonesbury: We never did any of those things.

Zonker: I know. But one day we'll think we did.

Garry B. Trudeau, Doonesbury Dossier: The Reagan Years (1984). 
[T]o restore popular government as they imagined it to have existed in an earlier and purer age. This could be done ... only by revivifying the morale of the citizen, and using his newly aroused zeal to push through a series of changes in the mechanics of political life-direct primaries, popular election of . . . initiative, referendum, recall . . . and the like. ${ }^{46}$

No matter how invigorating a vision this is of the Republic, this brief description identifies some of the design flaws of direct democracy. For one, the idea that there was a time when there was popular government "in an earlier and purer age" is for the most part imcorrect. The utopian visions of old puritan towns in New England voting upon every issue is a fabulist's concoction. In fact, many historians point out that the Puritan political experience was in some ways "hierarchical" and "authoritarian." 47 The people were ruled by their churches and their elders. In fact, the idea of pure democracy is one that was rejected quite early on in colonial America. One lotly debated issue in pre-Revolutionary America was whether the "imstruction" (a vote held by the people to mstruct their representatives low to vote in Parliament) should be made bindimg upon the representative. Extensive analyses of the history of the binding instruction have concluded that the "movement to make instructions binding failed completely."48 To urge that America was somehow driftimg away from its democratic roots is tantamount to building the history of the Republic upon a fallacy.

Furtlermore, the progressives took a device and implanted it in a patient with which it was completely incompatible. The progressives saw what they believed were successful uses of direct democracy im Switzerland, ${ }^{49}$ New England, ${ }^{50}$ and ancient Athens, ${ }^{51}$ and thought the lessons learned in those communities could be brouglit to this Republic. But the transplant of direct democracy was premised upon the fact that there was a willing host that had a revivified sense of morality. Richard Hofstadter

46. HOFSTADTER, supra note 6, at 257.

47. See Joshua Miller, Direct Democracy and the Puritan Theory of Membership, $53 \mathrm{~J}$. Pol. SCI. 57, 60 (1991). Miller notes that Puritans, although a source of democratic theory, thought of themselves as "an elected aristocracy"; see also id. at 62 (describing the political structures within the Puritans' religious organization).

48. MoRgan, supra note 5, at 215; see also John P. ReID, The CONCEPT OF REPRESENTATION IN THE AGE OF THE AMERICAN REVOLUTION 96-109 (1989) (discussing generally the history of the instruction and its failure to fully take hold in the nascent Republic); infra text accompanying notes 187-89 (discussing the binding instruction).

49. See Cronin, supra note 1, at 48; Ellis P. Oberholtzer, The Referendum in AMERICA 100 (1912).

50. See Alan Simpson, How Democratic Was Roger Williams?, 13 WM. \& MARY Q. 53, 65 (1956) (questioning the belief that New England was democratic by saying that "the skeptical doubts are unquenched").

51. See, e.g., MAGLeby, supra note 4, at 31 ("[M]any American Progressives traced the concept of direct legislation to ancient Athens ...."). 
asserts that progressives imagined that there was a new man-John $Q$. Public-who was to charge into the new century and "address himself directly and highmindedly to the problems of government."52 This allegorical "Man of Good Will" would be "intellectualistic" and "it was assumed that soinehow he would really be capable of informing himself in ample detail about the inany issues that lie would have to pass on, and that he could inaster their intricacies sufficiently to pass intelligent judginent."53 The assumption, however, proved wrong. It was wrong because a political device that worked on a sinall scale in a different time could not work on a far unore coinplex society and political context. For example, the proponents of direct deinocracy use the Puritans as an example of a successful direct deinocratic framework. While it is true that at some points in history there was no hierarchy in town governinent, the Puritans lived in a society in which the cliurcli hierarchy took the place of inany of the political frameworks of town government. ${ }^{54}$ The Puritans were, for the inost part, homogeneous and closely knit-bound together by the Church. ${ }^{55}$ More importantly, the Puritans came froin a political background quite hostile to liberalisin; ${ }^{56}$ meinbership in a coinmunity was soinething to be earned, not inerely assumed, and ineinbers were not equal. ${ }^{57}$ The contrast to America in the early 1900s could not be niore stark; Hofstadter remarks that the machinery of direct democracy "was less adapted to the realities of the highly organized society of the late nineteentli and the twentieth century" and was therefore "found of very limited use." 58 In effect, torn away from the context (the Yankee-Protestant idcal) whence it came, direct denocracy was "unintelligible"59 and "without meaning." 60 In examining the history of conteinporary direct

52. HOFSTADTER, supra note 6 , at 261.

53. Id. (emphasis added).

54. See Miller, supra note 47 , at 60.

55. Id. at 59.

56. Id. at 61 .

57. Id. at 63-64. This structure is comparable to the communitarian model of government. Communitarians posit that smaller, more cohesive communities where virtue and tradition can be emphasized will return society to a more organic state. The Communitarian vision will be examined more closely infra text accompanying notes 219-26.

58. HOFSTADTER, supra note 6 , at 261.

59. Id.

60. Id. at 267 (discussing Herbert Croly, Progressive Democracy 213-24 (1914)). 
democracy, ${ }^{61}$ one can begin to see its flawed design and its shaky foundations. ${ }^{62}$

\section{B. The Inadequacy of Filtering}

Considering the mythological history of direct democracy, one must question whether further buttressing can restore direct democracy and provide a sound design to preserve it for the future. Yet the reformers of direct deinocracy are inaking the same fundamental mistakes when they argue that the flaws of the referendum and mitiative can be corrected by judicial pre-passage review of procedural regularity and post hoc review of constitutionality. Professor Julian Eule's recent article ${ }^{63}$ illustrates the growing misgivings over direct dennocracy by the inheritors of the progressive movement. Professor Eule has all the premises right: He sees the problems and dangers, but his solution is to retain the status quo. Eule sees the solution to majoritarian excesses as stringent filtering by courts using expanded judicial powers under the Equal Protection Clause and the First Amendment. He views the "[f]ederal court imvocation of the Bill of Rights . . . [as] the only line of defense against majoritarian tyranny." 64

The problein with Eule's argument is threefold. First, on a practical level, the question of how and when to filter has proved an intractable

61. The same sort of analysis can be made of ancient Athens and Switzerland, though, for the reader, on a rudimentary level these societies are obviously different from twentieth-century America. For the Greek perspective, see Patricia Springborg, The Primacy of the Political: Rahe and the Myth of the Polis, 38 PoL. STUD. 83, 84 (1990), which argues that proponents of a return to ancient Greek traditions have mythologized ancient Greek society and ignored all the problems and differences, specifically, the absence of women from politics. See also ROBERT A. DAHL, DEMOCRACY AND ITS CRITICS 28 (1989) (arguing that because the Greeks disdained representative government, they realized that government on a large scale was impossible). For the Swiss perspective, see JAMES MILlER, ROUSSEAU: DREAMER OF DEMOCRACY (1984), which points out the paradox that Rousseau "was instrumental in propagating the image" of Switzerland as "an ideal democracy" when "inost cantons were in fact oligarchies." Id. at 41 (footnote oinitted).

62. With such a questionable structnral basis, the probleins of attempting to reform direct democracy are much easier to identify. One might argue that to truly restore the original vision of direet democracy, the flying buttress of judicial review should be completely eliminated; its removal would return the pristine lines of the original progressive's vision. This view found a powerful ally in Justice Hugo Black's defense of direet democracy in Reitınan v. Mulkey, 387 U.S. 369 (1967). Justice Black stated that the initiatives like the one at issue in Reitman are as near to denocracy as one could get in America. This remark was made in a spirited exchange with then-Solicitor General Thurgood Marshall in oral argunents before the Court. See 64 LANDMARK BRIEFS AND ARGUMENTS OF THE SUPREME COURT OF THE UNITED STATES: CONSTITUTIONAL LAw 672 (Philip B. Kurland \& Gerhard Casper eds., 1975); see also Eule, supra note 21, at 1506. But this "solution" merely ignores the problem. Surely eliminating judicial review would cause a complete collapse of the process. The addition of more judicial review is inadequate, but the total absence of any judicial review would be a far worse situation.

63. Eule, supra note 21.

64. See id. at 1584. 
problein. ${ }^{65}$ Second, judicial filtering has proved inadequate, and strengthening the courts' power as a filter does not address all the problems. ${ }^{66}$ Third, and likely disconcerting to those opposed to judicial activism, the courts have been particularly creative in finding direct democracy unconstitutional. ${ }^{67}$ In other words, when the courts beconie the final filter (maybe the only filter), in desperation they resort to very expansive and creative interpretations of the Bill of Rights. ${ }^{68}$

1. The Efficacy of the Courts as Filters. When one advocates a stronger role for the courts to filter direct democracy, one should first examine how well-equipped the courts are to do the job. The courts perforin best when they have clear issues presented before thein, with a complete record, in a timely context, and with strong advocates representing both sides. That is why the federal courts have constitutional and prudential rules of justiciability. ${ }^{69}$ This paradigm of justiciability, however, is often not available in the review of direct denocracy: The issue is opaque; the record is bare; the case is not ripe; and the parties are soinetimes hard to determine. The judges themselves are constrained by time and their interest in maintaining either their seats (in the case of elected state judges) or the public respect for the institution of the judiciary.

In fact, when one reads the work of the direct democracy reformers, one will be struck by their constant attention to the rules of justiciability and the efficacy of the courts. ${ }^{70}$ They read these rules as obstacles to solutions but do not seem to realize that there are some good reasons why those obstacles were put in place. The approach of reformers is to find out how to make a referendum or initiative reviewable, rather than to examine why direct democracy may be an inherently poor subject of judicial review. For example, Professor Eule presents what appears to be a perfect, logical proof: (1) Filtering must be done; ${ }^{71}$ (2) only state courts or federal courts can filter; ${ }^{72}$ (3) state courts are inappropriate to

65. See infra Part $\mathrm{I}(\mathrm{B})(1)$.

66. See infra Part $\mathrm{I}(\mathrm{B})(2)$.

67. See infra Part $\mathrm{I}(\mathrm{B})(3)$.

68. This argument is derived in part from Eric H. Zagrans's article on Section 1983 actions, "Under Color of" What Law: A Reconstructed Model of Section 1983 Liability, 71 VA. L. REv. 499 (1985). Zagrans argues the converse, i.e., that expansive hability under Section 1983 led to more opportunities for the conservative Burger and Rehnquist Courts to restrict substantive rights.

69. ERWIN CHEMERINSKY, FEDERAL JURISDICTION 43-124 (1989) (detailing the prohibition on advisory opinions, standing, ripeness, and mootness).

70. See, e.g., Eule, supra note 21, at 1579-84 (concluding that state courts are less suited to serve as filters than federal courts); James D. Gordon III \& David B. Magleby, Pre-Election Review of Initiatives and Referendums, 64 NOTRE DAME L. REV. 298, 304-13 (arguing that rules of justiciability can be overcome in certain types of cases).

71. Eule, supra note 21, at 1549.

72. Id. at 1579 ("[T]he question remains which judicial system is best suited for the role."). 
filter; ${ }^{73}$ therefore, (4) federal courts should be the filter. ${ }^{74}$ Q.E.D. The logic, however, contains a missing premise, that is, that federal courts are appropriate filters. If, in fact, that also can be negatived, then the proof does not work. Professor Eule, however, never discusses whether the federal courts can themselves provide the filter to the majoritarian tyranny he so much fears.

Filtering by the judiciary takes two general fornns: procedural and substantive review. Procedural filtering is done by state courts, since the procedures are created under the state constitution or statutory law. ${ }^{75}$ In Califonina, for example, there are several innportant requirements for direct democracy. ${ }^{76}$ The initiative or referendum has to cover a single subject; ${ }^{77}$ proponents must procure valid signatures from five percent of the electorate in order to place the measure on the ballot; ${ }^{78}$ and the full text must be subinitted to the state within a certain tinne period. ${ }^{79}$ If the procedural requirements are not inet, the state will not place the measure on the ballot. This kind of filtering, however, entirely depends on what the state accorded to ensure that small groups could not co-opt the process. ${ }^{80}$ Invariably, as long as there is procedural regularity, the measure will be placed on the ballot regardless its subject matter.

The most effective filtering courts can perforn concerns the constitutionality of direct democracy. Constitutional filtering (either based on state constitutions or the United States Constitution), though, has great costs to the judiciary. The courts are like ships hazarding the Scylla of pre-passage review and the Charybdis of post-passage review. If pre-passage, as some commentators have suggested as a possibility, ${ }^{81}$ the problem of justiciability arises. The court would be rendering an advisory

73. Id. at 1580 (concluding that there is "little hope that state courts will have either the ability or the desire to take a leading role in filtering").

74. Id. at 1584 .

75. For a comprehensive coverage of state requirements for direct denocracy, see MAGLEBY, supra note 4 , at $36-44$.

76. CAL. ConsT. art. II, $\S \S 8-10$.

77. Id. $\S 8(\mathrm{~d})$. The single subjeet requirement has been construed by the California courts as a substantive requirement of direct democracy and thus has been read as non-reviewable until after the passage of the ineasure. See Douglas C. Michael, Note, Preelection Judicial Review: Taking the Initiative in Voter Protection, 71 CAL. L. REV. 1216, 1227 (1983).

78. CAL. CONST. art. II, § 8(b), §9(b).

79. Id. $\S 9$ (b) (West Supp. 1991). The procedural requirements for initiatives were themselves amended by Proposition 109 in 1990. Id.

80. See generally MAGLEBY, supra note 4, at 65-70 (detailing studies which show that signature-gathering is the most difficult aspect of getting a measure on the ballot).

81. See Gordon \& Magleby, supra note 70, at 318. Gordon and Magleby criticize pre-election review except in two cases: first, where a "present, significant, irreparable injury to a fundamental public interest" is involved, and second, where there is procedural irregularity. Id. Their article presents the problems that result from pre-election review; they do not seem to realize that most of 
opinion. ${ }^{82}$ Further, the case is not ripe, in that it would be a waste of judicial resources to rule on the constitutionality of a law that has not been passed..$^{83}$ But the institutional costs are arguably even greater when the filtering is done after passage of the legislation. It is one thing, as one Califorria Supreine Court justice pointed out, to declare a legislative act unconstitutional, but it is quite another to declare the act of the people unconstitutional and to overthrow the voice of the people. ${ }^{84}$ Chief Justice Rose Bird, also of the Califorina Supreme Court, learned that lesson well when the voters of Califorria reinoved her from her seat on the court. The electorate purportedly was disillusioned with a court that first tried to limit the breadth of ${ }^{85}$ and then consistently skirted the death penalty statute which had been passed by referendum. ${ }^{86}$ The institutional costs to the judiciary sap the authority of the courts and place thein in the role of an anti-inajoritarian police officer.

The preceding discussion does not distinguish which kind of court is doing the reviewing. The distinction, however, is very inportant. State courts have advantages in being free from most of the justiciability doctrines created by the Supreine Court. In fact, several states with direct democracy do provide for advisory opinions from state courts. ${ }^{87}$ State courts, however, are vuhrerable to the problems of pohitical influence. One wonders how a state judge who faced re-election in the following year would rule on the constitutionality of an issue which had the approval of, say, $77 \%$ of the electorate. Professor Eule thinks the danger is too great. ${ }^{88} \mathrm{He}$ effectively argues that "[d]irect democracy ... poses a peculiar threat to state judicial independence. Judicial filtering of [referenda and initiatives] calls for nonaccountable judges." $89 \mathrm{He}$ reasons that if federal courts were created in order to insulate judges froin the vagaries of local politics, this appears to be the ideal situation for those courts to act upon those issues which are most vulnerable to local politics.

the problems they identify also exist in post-election review. Post-passage review may even exacerbate some of them.

82. See id. at 304-09.

83. See id. at 309-11.

84. See Eule, supra note 21 , at 1583 (quoting former Justice Joseph Grodin of the California Supreme Court).

85. See People v. Ramos, 639 P.2d 908 (1982), rev'd, 463 U.S. 992 (1983).

86. Justice Bird's removal reflects the kinds of problems raised by the recall. Although the vote was not technically a recall, inembers of the Supreme Court of California, 15 years after their appointment, must face a removal election. The lessons to be learned are the same about political accountability for judicial decisions. See Joel Sappell, Death Penalty Controversy Trails Bird, L.A. Times, May 14, 1990, at A1.

87. See, e.g., MASs. CoNST. ch. III, art. 2.

88. See Eule, supra note 21 , at 1579-84 (giving anecdotal evidence of the state judiciary being constrained by political pressure).

89. Id. at 1584 . 
Eule's suggestion that federal courts step to the fore, however, hides its underlying assumption that the federal courts themselves are up to the task. Federal courts will only be able to review ballot measures after they are passed because of the justiciability problem. Justiciability, however, is not merely a matter of constitutional law, it is also an exercise in prudence. Federal courts need to conserve their resources while making well-reasoned decisions. They need situations which provide them "concrete controversies best suited for judicial resolution."90 Direct democracy thrusts cases before federal courts with virtually uumanageable matters.

A special problem that arises with initiatives is statutory construction of such laws and was treated in a recent work.91 That Note advocates that the "traditional" method of interpreting legislation be used or else the judiciary will have "usurped" the voice of the people.92 It is unclear, though, what this voice is and whether there ever is an ascertainable intent. Because if it is the people who are the lawnakers, how are we ever to reconstruct their intent? If we merely take the drafters' intent (e.g., from the pamphlets handed out to voters, as is suggested), are we coinpletely trivializing the people's voice? The problein becomes even more complicated when one is presented with an initiative like Big Green..$^{93}$ If a voter cannot possibly have even read the initiative while in the voting booth, is it meaningful to try to reconstruct the intent of their vote?

The Supreme Court has the luxury to choose cases in which issues are presented clearly and unencumbered by extraneous matters. The courts that review direct democracy, however, have to take what is presented. Sometimes, even the parties are hard to discern. For example, in a case involving the constitutionality of an 'English only' initiative in Arizona, the circuit court had to first sort out who the parties to an appeal were before they could rule on the merits. ${ }^{94}$ Because the state constitutional amendment was passed despite the objections of then-Governor Rose Mofford-the named defendant-she had no inclimation to expend her resources to defend the case in court. After losing in federal district court in Yniguez v. Mofford, ${ }^{95}$ the proponents of the initiative

90. ChemerinsKy, supra note 69 , at 40 .

91. See Elizabeth A. McNellie, Note, The Use of Extrinsic Aids in the Interpretation of Popularly Enacted Legislation, 89 CoLUM. L. REv. 157 (1989).

92. See id. at 157.

93. Cal. Prop. No. 128 (1990).

94. Yniguez v. Arizona, 939 F.2d 727 (9th Cir. 1991). The appeal is still pending.

95. 730 F. Supp. 309 (D. Ariz. 1990); for a more complete discussion of the decision, see infra text accompanying notes $115-17$. 
wrangled over whether they were the proper party on appeal.96 The problem of justiciability (in the prudential sense) is present, where the issues are not concrete and the parties are not even adverse to each other. The Nimth Circuit held, oddly, that the sponsors of an initiative are the equivalent to legislators and are thus entitled to intervene, even if the only named party refuses to appeal. ${ }^{97}$

Fimally, whether or not the federal court does its job as a filter, the inajoritarian tyranny has already occurred. When the people of Arizona inandated that Enghish was the language to be spoken in the state, they had already done damage to the psyches of those for whom English was not their native tongue. When Californians voted on whether those stricken by AIDS should be quarantined or not, even though the initiative was defeated, one has to wonder whether the people should be allowed to even put such questions to vote. It worries one to think that the federal courts were the "only line of defense" had that passed.

Oncc the reformers agree (as they all do) that filtermg is imperative, they reflexively convince themselves that there is a time deterninate and a locatable court where judicial review can be efficaciously performed. They just need to find it. The reformers take their conclusion and work backward in their logic. They are like the archeologists who test each ancient cloth they find in the Middle East to ceternine whether it is the shroud of Turin. ${ }^{98}$ They do not stop to consider that the hypothesis they test itself may be wrong. These reformers of direct democracy never consider the possibility that there is no tine and no place when filtering can be properly done. This conclusion that there can be efficacious filtering of direct democracy is simply the result of an improper construction of the problem. The obstacles to effective filter mechanisms and the stakes are both too high to inake this inistake.

\section{No Exit: Filtering's Inadequacy in Curbing Public Choice.} The primary problem with post-passage filterimg, however, is that it norinally only takes the form of determining whether the legislation violates individual rights. Although that is an important (maybe the most inuportant) function of filtering, the process ignores a whole slew of other kinds of referenda such as public safety referenda. The First Amendment and the Equal Protection Clause buttresses are quite powerful in curbing such imitiatives as the one that declared English the official language of

\footnotetext{
96. See Yniguez, 939 F.2d at 727.

97. See id. at 733.

98. The shroud of Turin, legend has it, is the cloth in which the body of Jesus was buried.
} 
Arizona ${ }^{99}$ or the one which would place AIDS-stricken patients in quarantine in California. ${ }^{100}$ Nuclear power referenda, however, are unlikely candidates for equal protection review. The filters simply do not apply to certain types of direct denocracy. It is this type of direct democracy which presents a wholly different challenge to judicial review. The problem, here, is not majoritarian tyranny (with which Eule's article concerns itself) but is the problem of public choice run rampant.

One would assume that the purpose of referenda and initiatives is to create an instrument to give reality to political choices by the public. As political scientists have argued for years, voters do not bother to vote because they do not believe that they have any influence in the political choices made by their representatives. ${ }^{101}$ Direct democracy corrects this inertia by eliminating the middle man. ${ }^{102}$ There are generally two major problems with this theory of pure democracy: First, it assumes that majorities are rational; second, it assumes that a referenduin or mitiative can properly capture the desired policy choice. These two assumptions, however, are not directly addressed by the proponents of direct democracy. They are, instead, assumed away-as a matter of common sense or a mere problem of construction-when, in fact, these assumptions contain major flaws. With a referendum or mitiative, there is no exit; once the voter lias stepped into the booth, she cannot step out until she lias made a choice. ${ }^{103}$ That choice might be wholly irrational or a choice betwecn lesser evils.

Consider, for example, a voter presented with the 1988 Massacliusetts proposition to close the commonwealth's two nuclear power plants, Yankee Rowe and Plyinouth; at the time, Yankee Rowe had an unassailable safety record, whereas Plymouth had an abysmal one. Of course, voters exist along the whole spectrum of this issue, but one can probably categorize them into several broad groups that represent the spectrum:

1) Nuclear power at whatever cost;

2) Close any unsafe plant. Because Plymouth is unsafe, it should be closed, but Yankee Rowe should stay open;

3) Close any unsafe plant. Because Yankee Rowe and Plymouth are unsafe, they should both be closed;

99. Ariz. Amend. 5 (1988); Yniguez v. Mofford, 730 F. Supp. 309 (D. Ariz. 1990) (blocking the initiative on First Amendment grounds).

100. Cal. Prop. 64 (1986).

101. See Demetrios Caraley, Elections and Dilemmas of American Democratic Governance: Reflections, 104 PoL. SC1. Q. 19 (1989).

102. Of course, it nuay be precisely this "inertia" that was intended by the Framers, in the same way that separation of powers was nieant to curb unrestrained congressional, judicial, and executive power.

103. See MAglebY, supra note 4, at 188 ("Under direct legislation the decision is limited to a yes or no response to a typically conplex issue."). 
4) Close any unsafe plant. Because Yankee Rowe and Plymouth are both safe, they should not be closed;

5) No nuclear power plants, no matter what.

Both (1) and (5) represent possible irrational voter preferences. In other words, they may be guided by motives that do not correspond with the common good, i.e., they are not practicing democracy. Of course this does not mean that these preferences are irrelevant. Take, for example, the person who opposes nuclear power upon his behef that no nuclear power plant is safe. Despite evidence that the possibility of other kinds of power plants (because of their number) have a greater likelihood of being fatal to the general public than a nuclear plant, this person refuses to vote to keep them open. In other words, if there was full information, this voter would be voting against his own interests. There is quite a bit of evidence for this kind of voter irrationality. As one commentator lias argued: "Because voting is essentially cost free, it is conducive to extremes of altruistic and malicious expression, both of which tend to be dampened by the cost structure of private undertaking."104

But worse, what the referendum and initiative do is skew the result to the irrational group. The result is that, like a prism, the beams of one group become merged with those of another and train ouly one indistinguisliable beam down onto the floor. Referenda and initiatives do this by taking a practical infinity of political preferences and funnelling thein into two choices, often termed "voter overload."105 Preferences (2), (3), and (4) are rational choices to be made by the pohicyinaker. Altliough one may disagree over precisely wliat is "safe," or whether Yankee Rowe and Plymouth are in fact safe, we would likely not argue that the choices are irrational. If $I$ beheve that Yankee Rowe is safe, Plyinoutli is unsafe, and I am a rational voter, how do I vote? Whatever choice I nake is skewed to a view that I did not want, even inuphicitly, to endorse. The proposition was defeated in Massachusetts, but consider the consequences of the vote. It leads political leaders to beheve that the majority of Massachusetts voters beheve that Plymouth is a safe plant. No one will now take action against Plyinoutli when the people theinselves approved of keeping it open. What if, more seriously, the proposition passed and the majority of voters fell into preference (2), i.e., closing one

104. Geoffrey Brennan \& Loren E. Lomasky, Introduction to Politics AND Process: New EsSAYS IN DEMOCRATIC Thought 55 (Geoffrey Brennan \& Loren E. Lomasky eds., 1989). Professor Susan-Rose-Ackerman aptly sums up this view, which she labels the "Virgimia School," as meaning that "[a] vote should be understood as meaning only that the individual preferred to vote for a particular policy, not that he or she prefers the policy itself with its associated costs and benefits." Susan Rose-Ackerman, Justifying Democracy: A Review Essay, 106 PoL. Scl. Q. 313, 314 (1991).

105. See BARBER, supra note 39, at 203. The problem of overload occurs where "an infinite number of alternatives [is] placed on what is a fimite agenda." Id. 
but not the other, but they voted to close both because Plymouth was simply too dangerous to keep open. The referendum gave them absolutely no way to express that preference. In other words, the rational voter with a definite pohicy preference has been bundled up with irrational voters and ignorant voters to create a result that does not even express a pohicy choice preferred by a majority of voters. ${ }^{106}$

Big Green, the comprehensive enviroumental initiative in California, provides another useful illustration of the overloading problem. What if Big Green's failure to pass was based on the twenty percent of voters who believe im unrestrained big business and forty percent of those who believe that, althougli existing enviroumental protection laws are nisufficient, the protections presented by Big Green were incomprehensible, too expensive, or too comprehensive. The remaining forty percent believe in the passage of Big Green. It is quite clear, tlien, that a inajority-eighty percent-believes in the furtlier regulation of the environment rather than the status quo. But this was expressed as one indistinguishable group of sixty percent of the voters saymg "no." What kind of "voice" is this? The danger is that the California legislature will shy away from environmental protection laws because the people have said "no" to them. The irrational voters, thereby, have their view leveraged by the rational voters to appear much larger than they are in fact.

Benjamin Barber offers a two-level answer to the question on liow to solve the problem of voter overload. On the first level, he critiques the critics and says that "[t]hese questions lead to paradoxes in part because hiberal deniocrats pose them in the vacuum of abstract rationality, where they are stripped of historical and pohtical context . .."107 This is the common refrain of commumitarians such as Barber: that one cannot understand a system when one stands outside of it. This, however, has a simple retort: That's your problein, not mime. The commumitarians have conceived of a system of an entirely new order. They assume away the existence of a fundainentally stable system based on a constitutional

106. One interesting study applied economic frameworks to analyze spending behavior in school districts that set their school budget by referendum. See Thomas Romer \& Howard Rosenthal, Bureaucrats Versus Voters: On the Political Economy of Resource Allocation by Direct Democracy, 93 Q.J. ECON. 563 (1979). The study takes expenditure "setters" as those people who set the figure that the referendum is to be voted upon. The study assumes that there is some fall-back ("reversion point") figure if the ballot measure fails to pass. The study found that the larger the gap between the fall-back figure and what the inedian voter found to be an optimal figure, the higher the actual expenditure eventually voted upon. Therefore, "expenditures are generally greater, and never less, than the expenditure level for the competitive [no referendum] model." Id. at 564. One could conclude that the referendum is akin to blackmail for the median voter: the worse the result of not paying the blackmail, the higher the voter is willing to pay. At best, the study shows that resource allocation is generally less efficient when done by direct democracy.

107. BARBER, supra note 39, at 203. 
framework. The communitarians have the burden of justifying their system with the given premise that we already have a republic in place.

To be fair to Barber, he is one communitarian who does not retreat from the miphications of his new system and offers practical solutions. At the second level of his solution, he conceives of a voting ballot that offers several choices. ${ }^{108}$ Barber suggests that referendums and mitiatives could give voters multiple options in their vote. Although no state in the Umion has such a system, ${ }^{109}$ Barber claims that certaim parts of Switzerland have used such a ballot with soine success. ${ }^{110}$ He provides a sample referendun ballot on the public funding of abortion which contains two "YES" options and three "NO" options."11 Although this may solve the difficulties of voter overload, his solution creates far more intransigent probleins. First, again, Barber has assumed there will be a reawakening of the dormant voter. A multichoice ballot presumes that a voter will be informed on the choices and will make a reasoned decision. Barber expects that citizens will feel reconnected to their governance and will seize the day. Remeinber, however, that this is precisely what the progressives of the early part of the 1900 s thought would happen to the citizenry in their time. This proved to be a fatal flaw in the progressive movement, ${ }^{112}$ and it appears that Barber is doomed to repeat history.

A second problein with the Barber ballot is that when it delimits the options for the voter, it effectively ousts some citizens of their right to vote. Voters are told exactly how their vote can be expressed, and further expressions are not available. This problein is not solved by more choices, because every voter has a legal right to express an infinite nuinber of preferences. The power to set the agenda is necessarily the power to eliminate voters. For example, in Barber's ballot, there is no option for a voter to express that he is a strong supporter of abortion rights but does not beheve in federal funding of a health clinic of any kind. This person is automatically going to be included in a group with whoin he has no political will in common. Or one can return to the voting spectrum created for the nuclear power plant closure in Massachusetts and pretend that it is a hypothetical ballot. ${ }^{113}$ What of a voter

108. See id. at 286 .

109. Massachusetts, in fact, expressly does not allow it.

110. See BARBER, supra note 39 , at $286 \mathrm{n} .41$.

111. See id. at 286. One of the options is "(4) NO: I am opposed to the proposal to support abortion clinics from public funds in the way it is formulated here, but I am not necessarily against abortion clinics in principle. I suggest the proponents reformulate and resubmit their proposal." Id.

112. See supra Part I(A).

113. See supra text accompanying notes 103-04. 
who does not want Plymouth Nuclear Power plant to remain open because she finds the name morally reprehensible since Plymouth represents a colony which took away Native-American lands? She has no vote on this ballot. In a "yes" or "no" vote, she can at least express that intention. In a vote where options are limited, she cannot vote for the option she wishes.

The only way to capture properly voter intention is to have a ballot which allows every citizen to write in her purpose for voting the way she did. This, of course, wonld eliminate any benefit Barber's proposal would have because no legislator would be able to read every voter explanation. I am arguing, then, that any kind of ballot is unable to capture pohcy preferences on one issue. A yes or no ballot necessarily bundles voters together whereas a multichoice ballot unfairly limits the options which should be available to a voter.

3. The Failure of the Final Filter. Professor Eule acknowledges that "[t]raditional equal protection doctrine may be ill-equipped to afford protection" for certain types of referenda and initiatives. ${ }^{114}$ For example, in a recent lower court case, Yniguez $v$. Mofford, ${ }^{115}$ which involved an initiative declaring Enghish as the official language of Arizona, the new law was struck down as being violative of the First Amendment. ${ }^{116}$ The referendum was in the form of a state constitutional ainendment that would have required all state agencies and employees to conduct their affairs in English. The court reasoned tliat such a law violated the First Amendment because it was overly broad restriction on speech. The court was faced with a novel issue in First Amendinent jurisprudence. Although this law inay have been borne of racisin and xenophobia, it is not necessarily unconstitutional. ${ }^{117}$ The court was probably forced to conjure up this solution because otherwise it would have liad to approve of a law that was simply reckless and discordant. Thus, not only does direct democracy create impohtic laws, but also it presents courts with broad opportunities to expand the Bill of Rights.

Similarly, the Supreme Court had to address a question of the constitutionahty of a Washington referendum that banned the mandatory busing to school of any child. The facts of Washington $v$. Seattle School District No. $1^{118}$ are a paradigmatic example of the kinds of iconoclasin

114. Eule, supra note 21 , at 1567.

115. 730 F. Supp. 309 (D. Ariz. 1990).

116. See $i d$, at 310 .

117. Eule would probably express some surprise that the court did find the law unconstitutional in Yniguez; he had assumed that official English initiatives were unreachable by constitutional practice. See Eule, supra note 21, at 1567.

118. 458 U.S. 457 (1982). 
engendered by direct democracy. The City of Seattle was concerned that its school system was not racially integrated, and so it voluntarily undertook an effort to desegregate its schools. ${ }^{119}$ As an overt response to the school board's plan, an organization drafted and brought a state-wide initiative to ban school busmg of children. ${ }^{120}$ The initiative passed by a wide margin. The Supreme Court, however, in a momentous case for school desegregation, struck down the law as unconstitutional. ${ }^{121}$

Seattle School District No. 1 presents an interestimg study in the problems of direct democracy. Here was a local problem solved by a universal solution. As the Court argued, "the initiative ... has its most pernicious effect on imtegration programs that do "not arouse extraordinary controversy." "122 Even assuming that the school board's decision to integrate its schools by busing was incorrect in the case of Seattle does not inean that it was incorrect $\mathrm{m}$ all instances. The solution painted with far too broad a brush. The Court noted that "[t]he longstanding desegregation programs in [other counties] have functioned for years without creating undue controversy. Yet they have been swept away, along with the Seattle Plan, by Initiative 350."123 A local problein, in a true democratic republic, should seek a local solution. With a representative system, the sole recourse of the people who disagreed with the Seattle School Board was to vote thein out of office. There is no reason to beheve that this was not a sufficient solution. If the issue was so inuportant to the people of Seattle, they certainly could have used that as their criterion for voting on a candidate for the school board. The problen with the state-wide solution is obvious; the residents of other areas, who are not in any way affected by a school busing plan installed in Seattle, are deciding the issue for the people of Seattle.124 It niay be precisely because the people of Seattle, as a whole, supported the integration of their schools by busing that outsiders wanted to upset that plan.

The Bill of Rights, in essence, beconies a flying buttress that caunot fulfill its purpose to support the weight of direct democracy. Direct denocracy is producing laws that the republican structure-not the Bill of

119. Id. at 461 .

120. Id. at $461-63$.

121. See id. at 483-84.

122. Id. (quoting Hunter v. Erickson, 393 U.S. 385, 396 (1969) (Harlan, J., concurring)).

123. Id. at 484 n.27.

124. This is one instance where even a local referendum for the people of Seattle was a more desirable solution than the state-wide referendum. Although this Note would still disagree with the principles of local initiatives and referenda, the risks involved with them are certainly less dangerous because they involve much smaller areas and are more likely to involve homogeneous groups. Moreover, local initiatives and referenda do not have problems with constitutionality since the Guaranty Clause only requires state-not local-governments to be in a Republican Form. 
Rights-is designed to prevent. As one commentator posed the problem: "Under direct legislation, the task of safeguarding minority rights from majority tyranny is effectively left to the courts" even though the Framers placed that responsibility in the hands of elected legislatures. ${ }^{125}$ The republican framework provided a "filtering effect ... whereby a representative refined his constituents' express views into his own conception of wise public pohicy."126 The proponents of direct deinocracy have made the Bill of Riglts something that it simply is not: "the only line of defense agaimst . . . tyranny." 127

When there is no representative filter, the people are gettimg to put other people's rights to a vote. This was condemned movingly by Justice Jackson in his defense of the First Amendment in West Virginia Board of Education v. Barnette 128:

The very purpose of a Bill of Rights was to withdraw certain subjects from the vicissitudes of political controversy, to place them beyond the reacli of majorities .... One's right to life, liberty, and property, to free speech ... and other fundamental rights may not be submitted to vote; they depend on the outcome of no elections. 129

Although Justice Jackson was correct in statimg that the Constitution did "withdraw certain subjects from the vicissitudes of political controversy," the Justice identifies the wrong source of this protection. First and foremost, the Guaranty Clause protected individuals because it forced all states to govern througl representation. The representative would be the "moderating influence" in the Madisoman scheme.130

Governors, senators, members of Congress, the President, and state legislators have one characteristic in common: They are all bound to follow and uphold the Constitution of the United States. The Constitution itself requires this in Article VI, Clause 3.131 President George Bush presented an example of his allegiance to the Constitution when he insisted that he could not sign the congressional version of the Civil Rights

125. MAGLEBY, supra note 4, at 188 . Magleby convincingly cites James Madison's view that the Constitution protected minority rights from legislation by "passing [the public views] through the medium of a chosen body of citizens." THE FEDERALIST No. 10, at 73 (James Madison) (Charles A. Beard ed., 1948). This idea of filtering seems at once to agree with and contradict Julian Eule's filtering systen. Eule views filtering as a solely judicial function, whereas the Madisonians view filtering as a legislative function. See Eule, supra note 21, at 1525.

126. NaNCy MaVeEty, Representation RightS AND THE Burger Years 99 (1991).

127. Eule, supra note 21 , at 1584 .

128. 319 U.S. 624 (1943).

129. Id. at 638.

130. See MAVEETY, supra note 126 , at 100 .

131. See U.S. CoNST. art. VI, cl. 3 ("The Senators and Representatives [of the United States], and the Menibers of the several State Legislatures, and all executive and judicial Officers, both of the United States and the several States, shall be bound by oath or affirmation, to support this Constitution."). 
Act of 1991 because he beheved that it included an unconstitutional quota. 132 In other words, the Constitution of the United States has meaning, not only to the courts, but also to the drafters and signers of legislation. This has especially important imphications for state legislatures and governors. The California state constitution's oath of office, for example, requires the governor and all the legislators to state, "I, . . , do solemnly swear (or affirm) that I will bear true faith and allegiance to the Constitution of the United States."133 The oath should not be read as merely pro fornia; the Suprenie Court has treated those state governments and legislatures that scoff at their oaths to be at "war against the Constitution."134 In Cooper v. Aaron, ${ }^{135}$ an opinion issued under the names of all nine Justices, the Court held that the governor and the legislature of Arkansas were violating their constitutional oaths by not desegregating their public schools. The Court emphasized that not ouly were state courts bound by the United States Constitution, but that the Governor and the legislature were as well. ${ }^{136}$

It should be apparent from the foregoing discussion that direct democracy differs dramatically from state legislatures in that it offers no such constitutional limitations upon those who draft referenda and initiatives. Direct democracy allows lay drafters of laws to contradict directly the strictures of the Constitution. As common citizens, they are bound by no oath to uphold the Constitution; those who write the referenda and imitiatives are under no duty or obligation to make sure what they are drafting does not violate the Equal Protection Clause or the First Amendment. They, in fact, may be completely unaware of the constitutional probleins presented by their referendun or initiative. Or worse, they may choose to use direct democracy to flout the Constitution or the courts' interpretation of that document. Seattle School District No. 1 may be precisely such an example. When direct democracy bypasses the representative system, the very core of the republican structure is tainted.

\section{A Practical Guide to the Guaranty Clause}

The Constitution gave the United States a duty to guarantee that all state governments in the Union be of a Republican Form. Article IV,

132. Ann Devroy \& Sharon LaFraniere, Bush Outlines Objections to Civil Rights Proposal; President Says He Won't Sign 'Quota Bill,' WaSH. Post, May 18, 1990, at A6.

133. CAL. Const. art. 20, §3. But see MAss. Const. amend. 6 (amending id. ch. VI, art. I) (requiring only allegiance to the state constitution). One might wonder about the constitutionality of the Massachusetts oath in light of the requirements of Article VI of the U.S. Constitution.

134. Cooper v. Aaron, 358 U.S. 1, 18 (1958).

135. Id.

136. See id. at 18-19. 
Section 4 of the U.S. Constitution states: "The United States shall guarantee to every State in this Union a Republican Form of Government ...."137 The remainder of this Note will be devoted to trying to discover what the Framer's intended in putting this Clause in the Constitution. What did it mean-did it have any ineaning at all?

\section{A. The Justiciability of the Guaranty Clause: Questioning the Political Question Doctrine}

In Pacific States Telephone \& Telegraph v. Oregon, ${ }^{138}$ the only Supreine Court case to raise the question of whether direct democracy violated the Guaranty Clause, the Court decided to pass on the issue. The Court held that the Guaranty Clause was non-justiciable because it was a political question. ${ }^{139}$

Justiciability is a concept that is not at all apparent upon first glance; it is not found in the words of the Constitution. And, as every law student knows, Marbury v. Madison ${ }^{140}$ stated that it is emphatically the province of the judiciary to say what the law is, and, more specifically, what the Constitution means. ${ }^{141}$ The Guaranty Clause provided the impetus for what was probably the most formatively important decision in political question doctrine. ${ }^{142}$ The definitiveness of that decision lias been eroded by Baker v. Carr ${ }^{143}$ and the demise of the pohtical question doctrine has been predicted for years. ${ }^{144}$ The trend among commentators is to argue not over whether political question doctrine should be scrapped, but, rather, how fast and how much it should be. ${ }^{145}$ Indeed,

137. U.S. ConsT. art. IV, $\S 4$.

138. 223 U.S. 118 (1912).

139. See id. at 151.

140. 5 U.S. (1 Cranch) 137 (1803).

141. See id. at 177. When faced with the prospect of jumping through the hoops of justiciability doctrine, one inay be tempted to skirt around them as do political scientists when faced with such mundane tasks. See Andrew Levine, Electoral Power, Group Power, and Democracy, in 32 Nomos: MAJORITIES AND MINORITIES 251, 251 (John W. Chapinan \& Alan Wertheimer eds., 1990) ("It is beyond iny competence to provide arguments, grounded in Constitutional doctrine ....I am confident that with sufficient ingenuity, coinpelling legal arguments can be produced, and that in the right political conditions they can prevail. I shall therefore leave Constitutional questions for others to worry over ...."). As lawyers and law students, we have no such luxury.

142. See Luther v. Borden, 48 U.S. (7 How.) 1 (1849).

143. 369 U.S. 186 (1962).

144. See Arthur E. Bonfield, Baker v. Carr: New Light on the Constitutional Guarantee of Republican Government, 50 CALIF. L. REv. 245 (1962). See generally LAURENCE H. TRIBE, AMER1Can Constrtutional LAw \$§ 3-13, at 96-107 (1988); Martin H. Redish, Judicial Review and 'the Political Question,' 79 Nw. U. L. REv. 1031 (1985).

145. Compare Redish, supra note 144, at 1059-60 (arguing that the Suprenne Court's resort to the political question doctrine is an abdication of its Constitutional responsibilities and should be abandoned) with Louis Henkin, Is There a 'Political Question' Doctrine?, 85 YALE L.J. 597, 600-25 (1976) (arguing that the doctrine is superfluous and a relic of another era). 
the reports of its demise have not been greatly exaggerated; in only one case since Baker has the Supreme Court held that a question before it was a non-justiciable political one. ${ }^{146}$

Unlike any other provision of the Constitution, the Guaranty Clause places the duty upon-not the Congress, not the executive, not the judiciary-but the United States. What is especially unique and frustrating about the non-justiciability of the Guaranty of a Republican Form of Government is that it "expresses the full limit of National control over the internal affairs of a State," 147 while it is the only section of the Constitution which is per se non-justiciable. ${ }^{148}$ Although the Supreme Court has acknowledged this apparent paradox, it has seemed willing to live with it. ${ }^{149}$

Soine suggest, however, that the Guaranty of a Republican Form of Government is about to fall from pohtical question doctrime, and the Court is inerely preparing the way. Professor John Hart Ely expresses the hope that "this unfortunate doctrime-that all Republican Form cases are necessarily cases involving political questions-will wholly pass from the scene one of these days."150 Ely makes two important observations: First, that this special per se rule can be easily excised without a

146. See Gilligan v. Morgan, 413 U.S. 1 (1973); see also TRIBE, supra note 144, at 105 (suggesting that because the case fell in the area of explicit authorization to a coordinate branch, the Court had no choice but to invoke the doctrine). But see Goldwater v. Carter, 444 U.S. 996 (1979) (holding, by plurality, that the authority for the rescission of a treaty was a pohitical question).

Even the deference to the executive in military matters has been eroded in political question doctrine. A recent district court decision held challenges to the War Powers Act not to be barred by the political question doctrine (while still holding it non-justiciable for lack of ripeness). See Dellums v. Bush, 752 F. Supp. 1141 (D.D.C. 1990). It is interesting to coinpare Martin v. Mott, 25 U.S. (12 Wheat.) 19 (1827), which was cited with approval by both Chief Justice Taney in Luther, see 48 U.S. (7 How.) at 44 ("[a] question very similar to this"), and Justice Brennan in Baker, see 369 U.S. at 213 , with the recent decision of Perpich v. Departinent of Defense, 110 S. Ct. 2418 (1990). Martin leld the calling of militia to be a non-justiciable political question, see 25 U.S. (12 Wheat.) at 30-32, whereas in Perpich the Court never even touclied the issue of whether the militia clauses were political questions and assumed the case was justiciable, see $110 \mathrm{~S}$. Ct. at 2422-24. Perhaps it is revealing that the opinion of the Court in Perpich noted that Article IV, Section 4 was closely related to the militia clauses. See $110 \mathrm{~S}$. Ct. at 2421-22 n.4 (Stevens, J.). The decision is important because it deals with the exact issue that concerns the Guaranty Clause: whether the relationship between the states and the federal government is an inherently political one. It is rather mystifying that the Court did not touch on the justiciability of the case-or else it illustrates how far political question doctrine has fallen.

147. South Carolina v. Umited States, 199 U.S. 437, 454 (1905) (emphasis added).

148. See Pacific States Tel. \& Tel. v. Oregon, 223 U.S. 118, 146 (1912); Taylor v. Beckham, 178 U.S. 548, 578 (1900).

149. See Baker, 369 U.S. at 210. Perhaps the reason that the Court has lield on so tenaciously to the non-justiciability of the Guaranty Clause is because the original exposition on political question doctrine involved that very clause. See Luther, 48 U.S. (7 How.) at 42-43. To knock out the first bnilding block would threaten to collapse the entire doctrine.

150. John H. Ely, Democracy AND Distrust 118 n." (1980). 
wholesale departure from pohitical question doctrine. Second, that recent decisions of the Court must be read as signalling this trend. ${ }^{151}$

Luther v. Borden ${ }^{152}$ first crystallized the political question doctrine when the Supreme Court refused to exercise its judicial power in a dispute over which government was the legitimate one in Rhode Island following the Dorr Rebellion. In this instance, the Court's acquiescence to the political department was undoubtedly wise because to do otherwise might have called into question the Court's authority. ${ }^{153}$ What was at issue was not what is "republican," but rather which government's claim over the state of Rhode Island was more legitimate. There were no judicially manageable standards ${ }^{154}$ nor any way for the Court to avoid making an inherently pohtical decision. This reading of Luther turns not so mucli on whether this was a question for Congress but whether this was a question for the state. Later in its decision, the Court adverted to the eventually moinentous dictum that Article IV, Section 4 "rested with Congress ... to determine upon the means proper to be adopted to fulfil this guarantee."155

Once Luther v. Borden liad been decided, the outcome of Pacific States Telephone \& Telegraph v. Oregon ${ }^{156}$ was a foregone conclusion. In Pacific States, the Supreme Court examined the constitutionality of the nation's first referendum system in the state of Oregon. The referendum power was put into place by a state constitutional amendment ${ }^{157}$ and was used to enact a corporate tax of two percent on gross receipts. ${ }^{158}$ The referendum device was upheld by the Supreme Court of Oregon ${ }^{159}$ and the company appcaled to the Supreme Court. The Court was emphatic in holding that Luther was a "leading and absolutely controlling case."160 And once it made that decision, the conclusion followed that the case involved a pohtical question, since the Guaranty clause was a pohtical question. ${ }^{161}$

151. See id. at 122-23.

152. 48 U.S. (7 How.) 1 (1849).

153. See id. at 38-39; see also Ely, supra note 150, at 118 n.*; WILlIAM WIECEK, The GUARaNTEE Clause of THE U.S. CONSTITUTION (1972).

154. See Luther, 48 U.S. (7 How.) at 39-40.

155. Id. at 43.

156. 223 U.S. 118 (1912).

157. Id. at 134 n.1.

158. Id. at 135.

159. See Kadderly v. Portland, 74 P. 710 (Or. 1903).

160. Pacific States, 223 U.S. at 143.

161. Id, at 151. 
After so emphatically silencing the Guaranty Clause in Luther and Pacific States, the Court in Baker v. Carr ${ }^{162}$ established a system for analyzing political question doctrine wherein upholding the non-justiciability of the Guaranty clause surprisingly did not fit. Of course Justice Frankfurter was right in castigating the majority for the contradiction of reaffirming the principles of Luther and Pacific States while at the same time finding no pohtical question in a case that "in effect [was] a Guarantee Clause claim masquerading under a different label."163 Frankfurter concluded, however, that the voter reapportionment case presented a non-justiciable political question.

One can turn the argument around on Justice Frankfurter and argue that Baker, im effect, overrules both Luther and Pacific States's lolding that the Guaranty Clause is per se non-justiciable. Luther and Pacific States are understandably non-justiciable because they involved the impermissible judicial meddling in a state's pohtical affairs. But the inajority in Baker rejected that position empliatically in holding that political questions are those that involve the "relationship between the judiciary and the coordinate branches of the Federal Government, and not the federal judiciary's relationship to the States."164 That Justice Brennan used the Guaranty Clause cases to support this position is virtually incomprehensible, given that both Taney's opinion im Luther and White's opinion in Pacific States focused on the relationship between the judiciary and the state and only tangentially on the relationship of the judiciary to the coordinate branclies of the government.

The Baker v. Carr majority stands on moving ground; it either has to follow Frankfurter's retreat back into pohtical question doctrine or move with Ely and resurrect the Guaranty Clause. To remain in the middle is doctrinally illogical. The illogic hes in the Court's statements, on the one hand, that justiciability is not "wholly and immediately foreclosed," 165 and, on the other hand, that the justiciability of the Guaranty Clause is wholly and immediately foreclosed. Does not the Guaranty Clause deserve the determination "whether the duty asserted can be judicially identified and its breach judicially determined, and whether protection for the right asserted can be judicially molded"?166 Others have pointed out, with more specificity than this Note will do, that the criteria that Brennan set out to determine whether or not a case is justiciable ${ }^{167}$

162. 369 U.S. 186 (1962).

163. Id. at 297 (Frankfurter, J., dissenting).

164. Id. at 210 (emphasis added).

165. Id. at 198.

166. Id.

167. Id. at 217. 
are met by a Guaranty Clause case. One Note argues that the Guaranty . Clause, since it is textually committed to "The United States,"168 ineans that "all three branches are responsible for enforcing" it. ${ }^{169}$ Professor Eule also agrees. ${ }^{170}$ The federal courts could certainly address theinselves directly to the determination of the neaning of the Guaranty Clause, and sweep away this "unfortunate" doctrine of its nonjusticiability.

Moreover, Professor Ely suggests the argument that, following Baker v. Carr, the Suprene Court implicitly began to acknowledge the justiciability of the Guaranty Clause. ${ }^{171}$ In Reynolds v. Sims, ${ }^{172}$ the Court again returned to the issue raised by Baker v. Carr, whether a voter apportionment scheme could constitutionally dilute a citizen's vote. The Court held that such a schenie was unconstitutional because the Equal Protection Clause guaranteed to each citizen an equal vote. While one will not find an exphcit discussion of the justiciability of the Guaranty Clause in Chief Justice Warren's opinion for the Court, he employs all the terins and logic of a Guaranty Clause case. It inakes no sense for the Court to hold the criteria to decide a Guaranty Clause case judicially unmanageable while cavalierly employing the same criteria in an Equal Protection Clause case.

The Court specifically stated that "in a society ostensibly grounded on representative government, it would seen reasonable that a inajority of the people of a State could elect a majority of that State's legislators." 173 The Court tried to portray this as a part of "the concept of equal protection" as it "has been traditionally viewed." 174 The Court in Reynolds could not have reached such a conclusion without first implicitly finding that State governments were "ostensibly grounded on representative government." Warren added the word "ostensibly" to qualify his declaration, because he realized that there was no way to reach such a conclusion without invoking the Republican Forn found in the Guaranty Clause. But Ely argues that since Warren's view was nonsensical without such a grounding, it nust be read as a case which implicates the

168. U.S. CoNST. art. IV, $\S 4$.

169. Cynthia L. Fountaine, Note, Lousy Lawmaking: Questioning the Desirability of Legislating by Initiative, 61 S. CAL. L. REv. 733, 767 (1988). The Note also considers the Baker criteria of "a lack of judicially discoverable and manageable standards," "the impossibility of deciding without an initial policy determination," and "lack of the respect due to coordinate branches of government," 369 U.S. at 217 , and concludes that none of them should bar the justiciability of the Guaranty Clause. Fountaine, supra, at 766.

170. Eule, supra note 21 , at $1542-43$.

171. ELY, supra note 150, at 122-23.

172. 377 U.S. 533 (1964).

173. Id. at 565 .

174. Id. 
Guaranty of a Republican Form of Government: "Thus to be intelligible, Reynolds v. Sims . . . must be approached as the joint product of the Equal Protection and Republican Form Clauses."175 The Court, then, has already done the work to place the Guaranty Clause back into the realm of justiciability.

\section{B. What Is a Republican Form of Government?}

If the courts do find that the Guaranty Clause is not a pohtical question, they must delineate some criteria to determine whether direct deinocracy violates the Clause. What is a republican form of government? Is representative government a necessary and sufficient condition for a republican form of government? These are necessarily difficult questions because they involve reconstructing the history of our Repubhic and using words that have changed in meaning over the centuries. But these questions are no more difficult than asking what is "equal protection" or "cruel and unusual punishment." As Justice Frankfurter stated in Baker v. Carr, "[c]ertainly 'equal protection' is no more secure a foundation for judicial judgment of the permissibility of varying forms of representative government than is 'Repubhican Form.' "176 Just because courts inust necessarily make the difficult decisions does not mean the answers are ineffable. On the contrary, Chief Justice Marshall's words confer a responsibility upon courts to make the hard decisions: "It is emphatically the province and duty of the judicial department to say what the law is." 177

1. The Fiction of Popular Sovereignty and Direct Democracy. The argument that direct democracy is not a republican form of governinent would appear, at first blush, counterintuitive. If the people are sovereigu and all power is granted by thein, how can it be that they cannot reassert their power? ${ }^{178}$ The sovereignty argument has much rhetorical force, but it has rarely been closely examined. The Court in Pacific States Telephone \& Telegraph $v$. Oregon ${ }^{179}$ adverted to the sovereignty syllogism, stating in dicta that they did not see any logic to the telephone coinpany's

175. ELY, supra note 150 , at 122.

176. Baker v. Carr, 369 U.S. 186, 300-01 (1962) (Frankfurter, J., dissenting). Justice Frankfurter, however, reached the conclusion that neither was reliable, whereas this Note argues that although both are equally difficult inquiries, they are not impossible to plumb.

177. Marbury v. Madison, 5 U.S. (1 Cranch) 137, 177 (1803).

178. Dames \& Moore v. Regan, 453 U.S. 654 (1981), makes the general argument that the states can only have as much power as the people give them. See also LaURence H. Tribe, God Save THIS HONORABle COURT 5 (1985) ("The people of the nation remain the sovereign, and all the coercive power they have delegated to the government may be exercised only pursuant to the law.").

179. 223 U.S. 118 (1912). 
argument when "[t]he ultimate power of sovereignty is in the people, and they in the nature of things . . . must have a right to change their constitution." 180

The concept of popular sovereignty, however, is not as concrete as the argument may suggest. Consider the validity of the following argument: The Parliament of England has only so much power as the sovereign grants it. Parliament, bottlenecked by pohitical divisiveness, decides to return legislative power to the sovereign. The only problem is that the sovereign is the Quecn. No one would question the absurdity of such a result. ${ }^{181}$ Is there any theoretical difference between our sovereign, the people, and the sovereign of England, the Queen? Or is it a merely a rhetorical tool?

Recent historical analysis suggests that one should not place too mucl faith in the idea of popular sovereignty and its implications in our constitutional scheme. Popular sovereignty, at bottom, is a myth-a fiction. The people were never sovereign, but were led to believe so by the Federalist propaganda. Professor Edmund Morgan contends that "[James] Madison was inventimg a sovereign American people to overcome the sovereign states."182 The people reserved no sovereign power because they never had any power to begin witli; popnlar sovereignty was a inere empty promise from the Framers. Alexander Hamilton put it more bluntly, perliaps, in arguing tilat the Constitution was creating an aristocratic republic, that the people should be drawn naturally to a monarchy that was the perfect paternalistic blueprint. ${ }^{183}$ But knowing the states and the people could not swallow sucli an idea, the "fiction" of popular sovereignty sprung from Madison's mind. Popular sovereignty rests on an idea, albeit an appealing and visionary one, but nonetheless an inchoate idea. Thus, Marshall's classic statement that this was a government of laws, not people, was trner than the people wanted to believe.

180. Id. at 145 .

181. Caution should be taken not to take the analogy too far; it is merely an illustration that the idea of sovereignty is not at all clear, nor a foundational principle of our government. One interesting look at political inythology compared British children's retention in the belief of the Queen as their de facto ruler and American belief in concepts such as popular sovereignty. See ROBERT A. Dahl, Polyarchy: Participation AND Opposirion 168-75 (1971). Dahl notes that the English lose their cognitive belief in the Queen as ruler as they grow older, whereas Americans retain their mythological view of sovereignty. See also R.R. PALMER, THE AGE OF THE DEMOcratic Revolution: A Political History of Europe AND AMERICA, 1760-1800, The Challenge 239-40 (1959).

182. MORGAN, supra note 5, at 267.

183. See Gerald Stourzh, Alexander Hamilton AND THE Idea of RepublicaN GovERNMENT 38-40 (1970); see also THE FEDERALIST No. 84, at 361-67 (Alexander Hamilton) (Charles A. Beard ed., 1948) (Hamilton argued that there was no need for a bill of rights). 
2. A Stab at a Historical Definition of Republican. Insofar as the syllogism of direct democracy rests on popular sovereignty, it is an argument whose validity is a chimera. Direct democracy must retreat to more concrete ground, to the text of the Constitution. What was envisioned by the Framers to be constitutional forms of republican government? Professor Bruce Ackerman states the foundation principle of the Republic: "[T]he age of the polis is long passed .... Ouly an extensive republic will embrace the diverse population required to provide the social foundations for hiberal politics. This means that the best we can hope for is a representative democracy . . . "184 Does the "best," however, translate into the only form in our constitutional scherne? Ackerman leaves the question unanswered, but the Framers of our Republic surely did not. ${ }^{185}$

Prior to the time of the ratification of the Constitution, no state had a direct democracy, nor was any contemplating one. One commentator asserts that the Framers would have responded with abject horror if they knew that direct democracy was practiced by the states, for democracy was a word that "denoted the lowest order of society [and] was generally associated with the threat of civil disorder."186 There is some evidence to suggest that this was true in the prerevolutionary debate over whether to have instructions from the people to their representative on how to vote on a certain bill. The instruction was prevalent in the prerevolutionary period, ${ }^{187}$ especially im what is today New England, and soon there was a movement to make the instruction mandatory, i.e., the representative would be required to follow the people's instruction. But this "inovement to make instructions binding failed completely. . . . [R]epresentatives im England and America have never been legally or constitutionally bound to follow the instructions ...."188 Edmund Morgan asserts that the instruction was another product of the fiction of popular sovereignty and that the Framers wisely refused to let it becoine part of our Republic. ${ }^{189}$

184. Bruce A. ACKerman, Social Justice in the Liberal State $305-06$ (1980) [hereinafter ACKERMAN, SoCIAL JUSTICE] (emphasis added). Ackerman seems to have retreated somewhat from this position in his new work. See Bruce A. Ackerman, We tHe People 54-55 (1991). He now advocates a remvigoration of a national referendum system, so that the people, rather than the courts, can transform the Constitution. See id.

185. See Bernard Ballyn, The Ideological Origins of the American Revolution 282-83 (1967).

186. Id. at 282. John Marshall was to have said at the Virginia Convention, "Can the whole aggregate conmurity act personally? I apprehend that every gentleman will see the impossibility of this." BOYLE, supra note 8, at 114 (arguing against the passage of state referendun1 laws).

187. See Morgan, supra note 5, at 213. See generally REID, supra note 48, at 96-109.

188. MORGAN, supra note 5, at 215.

189. See id. at $230-33$. 
What was the understanding of republican at the time of the drafting of the Constitution? Direct democracy proponents cite Locke and Rousseau as supporting direct action of the people. ${ }^{190}$ They should look elsewhere for their support, argue several historians. ${ }^{191}$ Morgan criticizes those supporters of popular sovereignty who used John Locke's Two Treatises on Government 192 to bolster the ideological backing for replacing the Enghish monarchy witlı a parliamentary system. ${ }^{193}$ In fact, Locke's conception of the people's power was "profoundly conservative" and in his view "[t]he English people never, even fictionally, exercised their constituent power outside Parhiament. They acted only througli their representatives in the House of Commons." 194

Rousseau, too, "coinplained bitterly" of those who misconceived his division of government and sovereignty. 195 To Rousseau, "tlie glory of republican citizens" was not im popular activity but rather "im obeying their legitimate magistrates." 196 Democracy, at best, was a vision of utopia, but an unrealistic one. So the best function served by the people was "symbohic and ritualistic. They actually do very little."197 These are merely illustrative of how fraught with difficulty it is to use history to justify ideology.

The Constitutional Convention debates are hardly illuminating in defining what the Framers mcant by republican. James Madison's notes on the Guaranty Clause debate could be printed liere without substantially increasing the page lengtl of this Note. ${ }^{198}$ The reason for the Framers' inattention in defining tlieir terms is that they had a common

190. One particularly egregious example of misunderstanding Rousseau is found in CRONIN, supra note 1:

The central idea of Rousseau's political theories is that the people, being subject to the

laws, ought to be their authors. The moment people allow themselves to be represented, they surrender their freedom. Thus, every law that the people have not ratified directly is invalid; it is not a true law.

Id. at 39.

191. See Morgan, supra note 5, at 105; Judith N. Shklar, Men and Citizens: A Study OF ROUSSEAU'S SOCIAL THEORY (2d ed. 1985).

192. John Locke, Two Treatises of Government (Thomas I. Cook ed., 1947) (1690).

193. See MoRGaN, supra note 5, at 105-06.

194. Id. at 255-56.

195. SHKLAR, supra note 191 , at 19.

196. Id. (quoting Rousseau).

197. Id. at 20; see also Maurice Cranston, Introduction to JEAN-JAcQues Rousseau, THE SoCial CoNTract 30-31 (Maurice Cranston trans., Penguin Books 1968) (1762) (arguing that Rousseau "used the word 'democracy' in a rather distinctive fashion" and that it "might be less confusing to speak of him as a 'republican' ").

198. See James Madison, Notes of the Debates in the Federal Convention of 1787, at 320-22 (W.W. Norton \& Co. 1987) (1920). 
understanding of the ineaning of "republican." They could not have anticipated the consternation that the ambiguity of the definition of republican would cause among conteniporary historians and constitutional scholars.

The Guaranty Clause debate was centered on sone confusion over the original expression of the Clause as it was introduced: "That a Republican Constitution \& its existing law ought to be guarantied to each State by the U. States." 199 On the one hand, soine of the Framers seeined to view the Republican Form of Government Clause as a way for the general government to "suppress Rebellions," 200 and the sole "object of the clause was to inerely secure the States agst. dangerous commotions, insurrections and rebellions."201 On the other hand, one niay infer froin the comments of other participants that they beheved that the Guaranty Clause set limits on the constitutional structures adopted by the several states. Gouverueur Morris of Pennsylvamia stated that he found the clause "very objectionable" because he was "very unwilling" to see the laws and constitution of Rhode Island guaranteed by the United States. ${ }^{202}$ Morris's view seeins to support the argunient that a Republic was a well-defined and delimited form of government in the minds of the Framers. Another Framer also agreed with Morris and stated that he "was afraid of perpetuating the existing Constitutions of the States."203 The implicit reasoning of these two is that both beheved that the constitutions of niany states were not of a Republican Form, and that they would not want to be read as certifying any non-republican constitutions. When both views of the Guaranty Clause seenned to be talking past each other, Edinund Randolph of Virginia rose to clarify the issue for both camps, stating that the Guaranty had two distinct parts: "1. to secure Republican Government. 2. to suppress domestic coininotions. He urged the necessity of both these provisions." 204 When the final version was suggested, the two expressions were both included in the Guaranty Clause. ${ }^{205}$

The conclusion, though, that the Guaranty Clause had two objects-to secure the Republican Form of Governinent in the states and to protect against internal rebellion-does not help define "republican." The only way to glean the Framers' ineaning of "republican" is to go

199. Id. at 320 .

200. Id. at 321 (Luther Martin of Maryland).

201. Id. (James Wilson of Pennsylvania).

202. Id. at 320 .

203. Id. at 321 (William Houston of New Jersey).

204. Id. (emphasis added).

205. See id. at 322 (James Wilson). 
through the entire structure of the Constitution and see how the Republcan Form was integral to that structure. In fact, the Guaranty Clause was raised frequently as an important aspect of the Constitution.

The Federalist Papers more clearly define the requirement of representation in a republican form of government. ${ }^{206}$ Madison, for one, could not have been more explicit in condemning direct deinocracy in a republic: "The true distinction [of] . . . the American Governments, lies in the total exclusion of the people in their collective capacity ...."207 $\mathrm{He}$ observed that the absence of representation led to the danger of "particular inoinents in public affairs when the people, stimulated by soine irregular passion, or soine illicit advantage, or misled by the artful misrepresentations of interested men, inay call for measures which they theinselves will afterwards be the inost ready to lament and condemn."208 His admomition is probably too kind. Majorities normally do not retreat from their dangerous positions but cling desperately to thein. Critics of utilitarianisin inake the normative observation that inajorities are inherently dangerous because the utility of a majority suppressing the minority may outweigh the relatively slight disutility of a passive minority victim. ${ }^{209}$ In other words, it is absurd to expect a inajority to control itself, because in its view it is more utilitarian to carry out its tyranny.

To Madison, representation was a necessary and sufficient condition of a republic because it served as the most important barrier to majoritarian tyranny. He took care to define his terms: "A republic, by which I inean a government in which the scheine of representation takes place, ... promises the cure. ${ }^{210} \mathrm{He}$ cautioned that one not forget the "great points of difference between a deinocracy and a republic." 211 James Madison arose froin a proud tradition of liberalisin that had a respect for the voice of the people, but a fear of the uncliecked power of their sovereiguty. Jolin Stuart Mill wrote:

[W] hen society is itself the tyrant-society collectively over the separate individuals who compose it-its means of tyrannizing are not restricted to the acts which it may do by the hands of its political functionaries. Society can and does execute its own mandates; and if it

206. As Ely points out, however, we must keep in mind that the Federalist Papers are merely after-the-fact propaganda designed to ensure the Constitution's safe passage through the state conventions. See ELY, supra note 150 , at 5.

207. The Federalist No. 63, at 269 (James Madison) (Charles Beard ed., 1948). For an excellent discussion of the Madisonian rejection of pure democracy, see MORTON WHITE, PH1LOSOPHY, THE FEDERALIST, AND THE CONSTITUTION 136-45 (1987).

208. THE FEDERALIST No. 63, supra note 207, at 268.

209. See BARBER, supra note 39, at 18 (blaming this on liberalism and its version of "thin" democracy).

210. See The Federalist No. 10, supra note 125, at 72 (James Madison).

211. Id. at 73 . 
issues wrong mandates imstead of right, or any mandates at all in things with which it ought not to meddle, it practises a social tyranny more formidable than many kinds of pohtical oppression, since . . . it leaves fewer means of escape, penetrating much inore deeply into the details of life, and enslaving the soul itself. ... [T] here needs protection ... against the tyranny of the prevailing opinion and feeling, against the tendency of society to inpose . . . its own ideas and practices as rules of conduct on those who dissent froin thein . . .212

Mill's point is that when the people, rather than just a monarch, tyrannize, that tyranny brings with it a power to inake others conforn to their model of conduct. This, as Michel Foucault has said in other contexts, "coinpares, differentiates, hierarchizes, homogenizes, excludes. In short, it normalizes." 213 It is one thing to rail against the tyranny of the magistrate; it is quite another to protest against the disapprobation of your entire society. It is the most damaging kind of judginent because it brings with it the greatest psychological power to force others to conform..$^{214}$

Some carry Madison's vision to its far more revealing conclusionthat the Guaranty Clause protects individual rights. John Hart Ely suggestively posits that the Guaranty Clause should be read as a complement to the Fourteenth Amendment to protect rights of the people.215 There is some reason to beheve that soine of the Franers viewed the Guaranty Clause in the same hight. In the debate over whether the Constitution should have a bill of rights, Alexander Hamilton argued that a bill of rights would be superfluous because the Constitution provides "securities to republican government, to hiberty, and to property . . . in the express guaranty of a republican form of government."216 Thus the

212. John S. MiLl, ON LiberTy 63 (Gertrude Himmelfard ed., Penguin Books 1982) (1859). See generally Robert L. Simon, Pluralism and Equality: The Status of Minority Values in a Democracy, in 32 NomOS: MAJORITIES AND MINORITIES, supra note 141, at 207, 215-221 (describing some of the defenses of pluralism im a democratic state).

213. Michel Foucault, Discipline and Punish: The Birth of the Prison 183 (Alan Sheridan trans., 1977).

214. See Solomon E. Asch, Effects of Group Pressure upon the Modification and Distortion of Judgments, in ReAdings iN Social Psychology 174 (Eleanor E. Maccoby et al. eds., 3d ed. 1958). The Asch study gave a chilling illustration of the power of societal pressure to force a person to discount her own perceptions when they conflicted with the perceptions of the majority. The study had subjects walk into a room and try to identify which line among a group presented before them was longer than the others. The study's conspirators would choose one of the lines as longer though it clearly was not longer. The subjects would often deny their own senses and accede to their peers in the room and agree with their wrong view. Asch believed this revealed that "[i]ndividuals are highly sensitive to the structural qualities of group opposition." Id. at 183.

215. See ELY, supra note 150, at 122.

- 216. The Federalist No. 85, at 368 (Alexander Hamilton) (Charles A. Beard ed., 1948). It should be noted, however, that Hamilton probably had the most aberrant interpretation of what a "Republic" was. On the one hand, he behieved that it disallowed all titles of nobility, see THE FEDERALIST No. 84, supra note 183, at 362 , but at the same time he thought a monarchy was the 
Guaranty Clause, in conjunction with the constitutional structure of the republic, would obviate the need for a specific bill of rights because the minority's interests would never be put into danger. Although this view might strike some as naive (and perhaps a bit disingenuous), it does give weight to Ely's argument that the Framers did not intend the Guaranty Clause to be an einpty vessel.

The definitive view of the constitutional scheme, Madison's and the Federalists', had no place for direct democracy. The Framers envisioned a Repubhican Form of Government to be one that had a representative system. No other kind could protect agamst the dangers of inajoritarian tyranny. As Eule acknowledges, direct democracy is "constitutionally suspect," 217 but more than that, it has carved out a hallowed place in a constitutional scheme to which it has no claim of even belonging. Eule argues that the Guaranty Clause is a mere filter to state action, but as Hamilton pointed out, it was the only filter (until a bill of rights) in the Constitution. Thus it cannot be at the same "filter" level but is ratler the threshold inquiry to all state action, before any filtering happens.

\section{Strange Bedfellows: Direct Democracy and Civic Republican-} ism. If we suppose that the Constitution is a hiving, changing document, low does the changing conception of "republican" bear on the constitutionality of direct democracy? Professor Ely, for one, suggests that such an inquiry is not outrageous: "Neither is there anything special about the Republican Form Clause that suggests that a line of growth or development (like that the Court has given virtually every other constitutional phrase) would be mappropriate." 218 One place where the line has not yet been clearly drawn is between civic republicans and liberals. The most important debate in the recent past has been over the republican model of governance and its view of hberalism. It is a defining moment, now, for direct democracy to become a tool of either one movement or the other. The last century has shown that direct democracy is illiberal, but this Note will show that it is also counter-republican; direct democracy falls into neither ideological camp, and civic republicans should realize this and be repelled by it.

best republican form of government. See STOURzH, supra note 183, at 38-41. Many of his fellow Federalists disagreed with the idea that a monarchy was a republican form of government. Hamilton lamented to his dying days that the absence of a monarchy would eventually fell the nascent republic. Id. at 39. In other words, Hamilton goes the furthest in distrusting democracy; he would rather accept the necessary evil of a monarchy than turn over rule to the people.

217. Eule, supra note 21, at 1545. It is all the more amazing that Professor Eule tries to straddle the middle over the constitutionality of direct democracy after he makes this concession. How can a "hard look" by the courts somehow make that which is unrepublican republican?

218. ELY, supra note 150 , at 123 (footnote omitted). 
Civic republicanism has ganied a political cacliet anıong contemporary intellectuals, especially conservatives, and provides a broad theoretical basis for political reform. The legal academy lias taken it, too, and threatens to turn it into a beast of its own. ${ }^{219}$ Civic republicanism is a historical movement that tried to identify western and American political thought as being rooted in republicanism. ${ }^{220}$ This largely descriptive project becanie transformed into an ideology by a merger witli the philosophical movement known as communitarianism. ${ }^{221}$ The two effected this merger because they had a common enemy-liberalism. ${ }^{222}$ Liberalism adheres to the view that individual rights have primacy over the polity; the ultimate searcli in the liberal model is to find absolute, universal inoral imperatives to protect tlie individual. Civic, or prescriptive, republicanism ${ }^{223}$ empliasizes thiat moral values-what the Greeks called virtue-liave meaning ouly in relation to their contexts; ${ }^{224}$ liberalism has removed itself from morality's contextual terrain and, thus, lias lost itself. 225 The only way to reorient morality is to return to a community

219. For a view of the breadth of the movement, see the Symposium issue in the Yale Law Journal, The Republican Civic Tradition, 97 YALE L.J. 1493-1723 (1989). Among the participants were Frank Michelman and Cass Sunstein. As Bruce Ackerman explains the recent revival among the lemming-like legal community, "wouldn't it be foolish for lawyers to ignore the 'republican revival' among American historians?" ACKERMAN, WE THE PEOPLE, supra note 184, at 25.

220. See J.G.A. Pocock, The Machiavelian Moment: Florentine Political Thought and the AtIantic Republican Tradition (1975); Gordon S. WOOD, The CreaTION OF THE AMERICAN REPUBlic, 1776-1787 (1969); HaNNAH ARENDT, The Human CondiTION (1958); BAILYN, supra note 185.

221. See MAcINTYRe, supra note 11; AlASDaIR MACINTYRE, WhOSE Justice? Which RATIONALITY? (1988); Michael J. SANDEL, Liberalism aNd THE Limits of Justice (1982); WALZER, supra note 38; BARBER, supra note 39.

222. The evil of liberalism, to those like MacIntyre, is that it emphasizes individual rights (which arrive in absolute, not contextual, terms) over community values. For the classic work on inodern liberalism, see JoHn RAwLS, A TheORY of Justice (1971); see also ACKeRMAN, Social Justice, supra note 184. MacIntyre identifies liberalism as the root of the "unsettable character of so much contemporary moral debate" and "the pluralism which threatens to submerge us all." MACINTYRE, supra note 11 , at 226.

223. Civic republicanism is a synonym for communitarianism and prescriptive republicanism. Paul Brest pointed out that the term civic republicanism is probably redundant, so he preferred republicanism or the republican revival. Further Beyond the Republican Revival: Toward Radical Republicanism, 97 YALE L.J. 1623, 1623 n.1 (1988). I will use civic republicanism for simplicity's sake, because it is the current term used by most legal seholars.

224. See MACINTYRE, supra note 11, at 273. MacIntyre insists that morality, or what he calls an account of the virtues, "can ouly be elaborated and possessed within an ongoing social tradition." Therefore he is exercised by any liberal search for universal truths; to communitarians, there is no such thing.

225. One communitarian describes the difference between the two movenients: "[W] liberal regards the expansion of individual rights and entitlements as unqualified moral and political progress, the communitarian is troubled by the tendency of liberal programmes to displace politics from smaller forms of association to more coniprehenisve ones." Michael J. Sandel, Introduction to Liberalism AND ITS Critics 6 (Michael J. Sandel ed., 1984). 
model of government where traditions and virtues bind together the members of the community. Therefore, moral imperatives-in their proper contexts-will be reinvigorated. 226

On its face, direct democracy seems to dovetail nicely with the revival of civic republicanism; what better way to allow the community to reassert itself than by letting the people vote? Both Michael Walzer ${ }^{227}$ and Benjamin Barber ${ }^{228}$ take up the communitarian call, and come forward with participatory democratic frameworks to institutionalize civic republicanisin. Walzer's franiework for a community is quite subtle in stating the kinds of participation that are acceptable. In Spheres of Justice, he einphasizes a structure in whicl social goods are distributed into spheres across the whole panoply of one's life: the government, the school, the workplace, the church, and the individual level. Within each sphere he encourages vigorous participation, but participation takes the form of the "citizen ... be[ing] ready and able, when his time conies, to deliberate with his fellows, histen and be histened to."229 Walzer makes clear that a citizen is not guaranteed equal power but merely equal opportunity to exercise one's political power. ${ }^{230} \mathrm{He}$, therefore, rejects the "push-button referenda" as "only anotlier example of the erosion of value-a false and ultimately degrading way of sharing in the making of decisions."231 Walzer reaches this moment, I believe, for two reasons. First, as a communitarian, he is sensitive to the constant criticism by liberals that communitarianism abhors pluralism and nay result in tyranny. ${ }^{232}$ Second, he clearly sees the mistake of trying to adopt a mythological view of the Greek polis and to foist it on modern society. In fact, Walzer agrees that the "great orator has long since lost his dominance," 233 meaning that the Greek polis lias succunibed on the political landscape. ${ }^{234}$

226. A discussion of the relative merits of liberalism and communitarianism is far beyond the scope of this Note. This Note only analyzes how well direct democracy fits within the communitarian model and whether communitarians shonld adopt direct democracy as one of its institutions. I employ criticisuns of communitarianism, not for substantive force, but to show how direct democracy does not fit together well within the communitarian model.

227. See WALZER, supra note 38.

228. See BARBER, supra note 39.

229. WALZER, supra note 38 , at 310 .

230. See id. at 309 .

231. Id. at 306-07. Walzer rejects direct democracy even while hypothesizing a system of full information, informed citizens, and healthy dialogue. He simply sees this as "[t]he casual or arbitrary exercise of power" and ultimately "morally unsatisfying politics." Id. at 310 .

232. The last pages of his book address the problem of tyranny in a communitarian state. See id. at 312 .

233. Id. at 304.

234. Walzer notes that "[u]nder modern conditions, [a citizen participating in the polis] would have to attend to a much greater variety of settings-cominittees, caucuses, parties, interest groups, 
Barber, however, has no such misgivings about reconstructing the polis and advocating direct denocracy in Strong Democracy. Barber's "strong democracy" system

rests on the idea of a self-governing community of citizens who are united less by homogeneous interests than by civic education and who are inade capable of common purpose and mutual action by virtue of their civic attitudes and participatory institutions rather than their altruism or their good nature. ${ }^{235}$

A close examination of Barber's language reveals his deep ties to civic republicanism. Embedded in this brief passage is a beckon to the alliterative "commumity," "civic education," and "common purpose," and an attack on the usual suspects- hiberal-sounding concepts such as "altruism" or "good." Upon this commumity, Barber wants to rest a system where representative democracy is pushed aside in favor of direct deınocratic practice. ${ }^{236}$ Included in these institutions will be a new, and newfangled, initiative process. ${ }^{237}$

Barber's framework, however, rests on false preınises. First, his conception of community is nonsensical. Barber explicitly states that his conception of the "community" is "umited less by homogeneous interests than by civic education." This definition of commumity has no meaning, however. Barber has a problem: His concept of commumity is logically incompatible with heterogeneous groups and large numbers of people. The meaning of community requires, as stated by MacIntyre, that they remain in "local forms" and relatively homogeneous, not pluralistic and universal, forms. ${ }^{238}$ But Barber wants to build community not only out of localities but out of states and nation-states. He therefore grafts on this idea that commuinty can be derived from mere "civic education" and need not undergo an inımersion in community values as Macintyre requires. This, however, is another example of what MacIntyre might term nonsense- when we use the key terms of analysis in our own way, for our own purposes but have really lost all meaning of those terms. ${ }^{239}$

and so on-and then to a greater variety of rhetorical styles." Id. at 304. The polis is not something that can be easily reimposed on an American society that has exponentially changed from ancient times.

235. BARBER, supra note 39 , at 117.

236. See id. at 261-311.

237. See id. at 281-98. The specifics of Barber's referendum instrument are discussed supra text accompanying notes 108-13.

238. See MacINTYRE, supra note 11, at 263 (emphasis added). A recent piece by Professor Lea Brilmayer illustrates the current uncertainty of the incaning of community. See Lea Brilmayer, Liberalism, Community, and State Borders, 41 DukE L.J. 1 (1991). Brilmayer suggests that there may be such a thing as a "world commumity." Id. at 22. The term is a virtual oxymoron; MacIntyre's concept of commumity necessitates the finding that American society, let alone the world as a whole, "cannot hope to achieve moral consensus." MACINTYRE, supra note 11, at 252.

239. See MACINTYRE, supra note 11, at 1-2. 
Without a concept of community that can ground his framework, Barber has a project in free-fall. If there is no theoretical basis for strong democracy, what practical hope is there for the success of this framework? This is simply another misconception of the polity and anotlier project-not unlike the progressive movement of the early part of the century 240 about to hit the ground witl a thud.

Barber's unremitting attack on liberalisin suggests another practical problem. Barber rehashes the arguments that lost over two centuries ago at the Constitutional Convention. For example, Barber insists that representative government is mcompatible with freedom, equality, and social justice. ${ }^{241}$ Barber is taking his framework so outside the Constitution that it lias no practical force. ${ }^{242}$

Fmally, aside from the theoretical inconsistencies, Barber ignores the practical problems with mixing commumitarianism and direct democracy. Direct democracy's great weakness is its mability to curb the majoritarian will; communitarianism's great vulnerability is to majoritarian tyranny. Together, the situation is ripe for disaster. One commentator cogently argues that it is the very groups that are in need of protection (what lie calls the "marginal persons"243) that are placed at risk by commumitarianism:

It is precisely because these groups are demanding more than the "community" or the polity wishes to grant them that these controversies exist in the first place. Thus, any "renewal" ... of community ... will accomplish nothing...; for them, the existence of any community is part of the problen, not part of the solution. ${ }^{244}$

Commumitariamism is designed for the "homogeneous" and the "tiny political umit"; so the problems of "marginal persons" are only exacerbated by mcreasing the size of the pohtical unit. To illustrate tlis point, consider two communities, A and B. A is of one race, B is of another race, and $A$ is substantially larger than $B$. When the two are separate hoinogeneous communities, the marginalized members of those communities are relatively small im number, for example, the disabled in community $A$ and members of a third race who live within $B$. If, however, the pohtical unit is increased whereby $A$ and $B$ become one whole unit, it

240. See supra Part $\mathrm{I}(\mathrm{A})$.

241. See Barber, supra note 39 , at 145-46.

242. Perhaps this is unfair to Barber; he may not care at all whether his framework is constitutional or not, because he is concerned more with theoretically sound frameworks and not with the mundane and largely irrelevant arguments of judicial review.

243. See Hirsch, supra note 27 , at 424 . Hirsch gives as examples of marginal people, the disabled, aliens, and homosexuals. Id.

244. Id. 
is clear that suddenly the members of B additionally become a marginalized group. Although this is merely a schematic illustration, it does show why Barber's framework is extraordinarily dangerous, ${ }^{245}$ especially if his definition of community is wrong. ${ }^{246}$

What theoreticians have to begin to realize about civic republicanism is that it is generally a philosophical movement and not given easily to practical apphication. In MacIntyre's vision of morality, community and virtue are inextricably intertwined with one another. One cannot piecemeal choose what parts of commumity to adopt and which to reject; they must go together or else they are meaningless. ${ }^{247}$ Barber's attempt to take the parts of community that he likes, reshape thein and meld thein with his own, and then apply it, is an impossibility. Ultimately, this definition of community is so inelastic that any attempt to stretch it to encoinpass direct democracy will fail. Civic republicans must either side with Walzer in rejecting direct democracy, or travel with Barber into the "new dark ages."248

When Roger Maris of the New York Yankees hit his sixty-first home run against the Boston Red Sox on October 1, 1961, he surpassed the legendary achievement of Babe Ruth, who had hit sixty home runs im 1927.249 This straightforward history is complicated by the fact that Maris accomplished his feat in a season that had 162 gaines, whereas Ruth had only 154 . The controversy created a fiction: that Roger Maris's smgle season home run record would go into the record books with an asterisk next to it indicating that he had done it in a 162-game season. As a point of fact, no asterisk ever existed; most baseball encyclopedias inerely mcluded both Maris's record and Ruth's record under the same heading. But the myth of the asterisk had more power than the reality. The people began to beheve that the asterisk existed; debate raged over whether the asterisk should be excised or not. The myth of

245. See Adeno Addis, Individualism, Communitarianism, and the Rights of Ethnic Minorities, 66 Notre DAME L. Rev. 1219, 1251, 1261 (1991).

246. See supra text accompanying notes 235-39.

247. Unfortunately, Bruce Ackerman's newest work arrived too late to be addressed more cogently by this Note. See ACRERMAN, We THE PEOPLE, supra note 184. Ackerman suggests that we dispense with the schism between hiberalism and republicanism. See id. at 29 . He envisions a dualist democracy in the Uinited States that incorporates parts from both visions of the Republic.

248. The term is Macintyre's. MAcINTYRE, supra note 11, at 263.

249. See Murray Chass, Maris's Feat Finally Recognized 30 Years After Hitting 61 Homers, N.Y. Trmes, Sept. 5, 1991, at B12; Shirley Povich, Frick's "Asterisk" Demeaned Maris, WASH. Post, Sept. 7, 1991, at D7. 
the asterisk was altering reality, so much so that Maris's accomplishment was being corrupted by the asterisk.

In 1991, thirty years after Maris's feat, the Committee on Statistical Accuracy led by Commissioner Fay Vimcent announced that the asterisk was to be reinoved froin record books. With this announcement (and its accompanying press releases and press conferences), Fay Vincent shattered the myth. Vincent's statement that "[t]his change allows Roger Maris to receive the recognition he deserves ...."250 sounds ridiculous. How would the elimination of something that did not exist make any difference in the real world? But Vineent was right. To ignore the myth would have been to allow it to thrive and reify itself. To address it as a myth and disassemble it-although it appears redundant-destroyed the inyth. Roger Maris's son said with seeming relief, "Obviously, it's great. I never felt it should have been put there to begin1 witll."251 But, of course, it never had been put there to begin with.

The mythology of direct democracy, too, has to be excised from our constitutional context. It never was there, and never should have been there-but, paradoxically, it is there. We want to believe that we liave a governmental structure that we simply do not have. To destroy the inyth, one sliould histen to Justice Ohver Wendell Holmes' words in BiMetallic Investment Co. v. State Equalization Board:252

The Constitution does not require all public acts to be done in town meeting or an assembly of the whole. General statutes ... are passed that affect the person or the property of individuals, sometimes to the poimt of ruin, without giving them a chance to be heard. Their rights are protected in the only way that they can be in a coinplex society, by their power, immediate or remote, over those who make the rule. ${ }^{253}$

On the one liand, we have to see the reality that we have a system that can put us at the "point of rum, without giving [us] a chance to be heard." This is a stark reality, but it yields a more important role for tlie citizen ("the only way ... in a complex society") to exercise her "power" over her representatives. Our system is premised on our representatives-our legislatures-being held accountable for the decisions they make. Once we begin to see the legislature, not as an obstacle to action, but as a vehicle to action, we can truly begin to recover the governance of

250. William Gildea, Straight Up: Maris 61, Ruth 60; Stats Committee Also Declares Haddix Game Imperfect, WASH. Post, Sept. 5, 1991, at B1 (quoting Fay Vincent, Commissioner of Baseball).

251. Id. (quoting Roger Maris, Jr.).

252. 239 U.S. 441 (1915).

253. Id. at 445 . This case is a seminal one in administrative law, but its sentiments are apposite to direct democracy. 
our affairs. The longer we are led astray by the myth of direct democracy, the further we are from regaining our Republic. 